\title{
The human papillomavirus 16 E6 protein can either protect or further sensitize cells to TNF: effect of dose
}

\author{
M Filippova ${ }^{1}$, TA Brown-Bryan ${ }^{1}$, CA Casiano ${ }^{1}$ and \\ PJ Duerksen-Hughes*,1 \\ 1 Department of Biochemistry and Microbiology, Center for Molecular Biology \\ and Gene Therapy, Loma Linda University School of Medicine, Loma Linda, \\ CA 92354, USA \\ * Corresponding author: PJ Duerksen-Hughes, Department of Biochemistry and \\ Microbiology, Center for Molecular Biology and Gene Therapy, Loma Linda \\ University School of Medicine, 11085 Campus Street, 121 Mortensen Hall, \\ Loma Linda, CA 92354, USA. Tel: 9095584300 ext.81361; \\ Fax: 909558 0177; E-mail: pdhughes@som.llu.edu
}

Received 08.11.04; revised 28.4.05; accepted 29.4.05; published online 03.6.05 Edited by JM Hardwick

\section{Abstract \\ High-risk strains of human papillomavirus, including HPV 16, cause human cervical carcinomas, due in part to the activity of their E6 oncogene. E6 interacts with a number of cellular proteins involved in host-initiated apoptotic responses. Paradoxically, literature reports show that E6 can both protect cells from and sensitize cells to tumor necrosis factor (TNF). To examine this apparent contradiction, E6 was transfected into U2OS cells and stable clones were treated with TNF. Intriguingly, clones with a high level of E6 expression displayed an increased sensitivity to TNF by undergoing apoptosis, while those with low expression were resistant. Furthermore, TNF treatment of cells in which the expression of $E 6$ was regulated by the addition of doxycycline demonstrated clearly that while low levels of E6 protect cells from TNF, high levels sensitize cells. Together, these results demonstrate that virus-host interactions can be complex and that both quantitative and qualitative aspects are important in determining outcome. \\ Cell Death and Differentiation (2005) 12, 1622-1635. \\ doi:10.1038/sj.cdd.4401678; published online 3 June 2005}

Keywords: apoptosis; HPV 16; E6; TNF; caspase activation; dose dependence

Abbreviations: HPV, human papillomavirus; TNF, tumor necrosis factor

\section{Introduction}

High-risk strains of human papillomavirus (HPV), including HPV 16 and 18, are responsible for most cases of cervical carcinoma in humans, ${ }^{1}$ and the transforming ability of this virus is attributed primarily to its E6 and E7 oncogenes. The first well-characterized activity of E6 was to bind to and accelerate the degradation of the p53 tumor suppressor, ${ }^{2}$ but E6 also interacts with a number of additional cellular proteins that are engaged in a variety of cellular processes. These include proteins involved in the regulation of transcription, DNA replication and proliferation such as $\mathrm{p300/CBP},{ }^{3,4}$ IRF$3,{ }^{5} \mathrm{hMcm} 7,{ }^{6,7}$ E6TP1 $1,{ }^{8}$ ADA $3,{ }^{9,10}$ TRIP-Br $1^{11}$ and tuberin ${ }^{12}$; proteins involved in apoptosis and immune evasion such as Bak, ${ }^{13} \mathrm{c}-\mathrm{Myc},{ }^{14,15}$ tumor necrosis factor (TNF) $\mathrm{R} 1^{16}$ and $\mathrm{FADD}^{17}$; proteins involved with epithelial organization and differentiation such as paxillin, ${ }^{18}$ E6BP/ERC-55, ${ }^{19}$ zyxin $^{20}$ and fibulin- $1 ; 21$ proteins involved in cell-cell adhesion, polarity and proliferation control that contain a PDZ-binding motif such as hDLG, ${ }^{22,23}$ hScrib, ${ }^{24}$ MAGl-1, ${ }^{25,26}$ MAGI-2, MAGI-3 ${ }^{27}$ and MUPP $1 ; 28$ and proteins involved in DNA repair such as $\mathrm{XRCC}^{29}$ and 6-O-methylguanine-DNA methyltransferase. ${ }^{30}$ However, with some exceptions, the mechanisms and consequences of the interactions between E6 and its cellular partners for either the host or the virus are not well characterized.

One common host response to virus infection is to trigger apoptosis, and this is often carried out through members of the TNF superfamily. In response, many viruses have developed ways to avoid this destruction of their host cells (reviewed by Benedict et al. ${ }^{31}$ and Benedict ${ }^{32}$ ). Work by our laboratory and others has suggested that the papillomavirus E6 protein may function in immune evasion by modifying an infected cell's response to such apoptotic stimuli (reviewed by Finzer et al. $^{33}$ ). Paradoxically, while some studies report that E6 sensitizes cells to apoptosis induced by TNF, ${ }^{34,35}$ others report that it protects cells from TNF. ${ }^{16,36}$ The apparent contradiction regarding the effect of E6 on a cell's response to TNF is currently unresolved and suggests that the effect of E6 on a given cell will depend on the cell type, cellular environment, factors associated with the expression of E6 and/or on the experimental approaches used, although no mechanistic basis for this has been proposed.

In this study, we found that for a given cell line, E6 can both sensitize cells to and protect cells from TNF, depending on the amount of E6 expressed. Low levels of E6 lead to protection from TNF, while high levels lead to sensitization. Not only do these results suggest a resolution for the discrepant findings in the literature, but they will also impact the development of molecular models for the interactions of these proteins and the dynamics of host-virus interactions. As such, they have relevance to the development of novel and effective approaches to the treatment of cervical cancer.

\section{Results}

\section{CaSki cells are sensitive to TNF, while SiHa cells are resistant}

CaSki and SiHa cells, both derived from human cervical carcinomas, contain the HPV genome and are frequently used as models for the biological effects of HPV. SiHa cells contain the HPV genome at 1-2 copies per cell, while CaSki cells contain about 600 copies of the HPV 16 genome per 


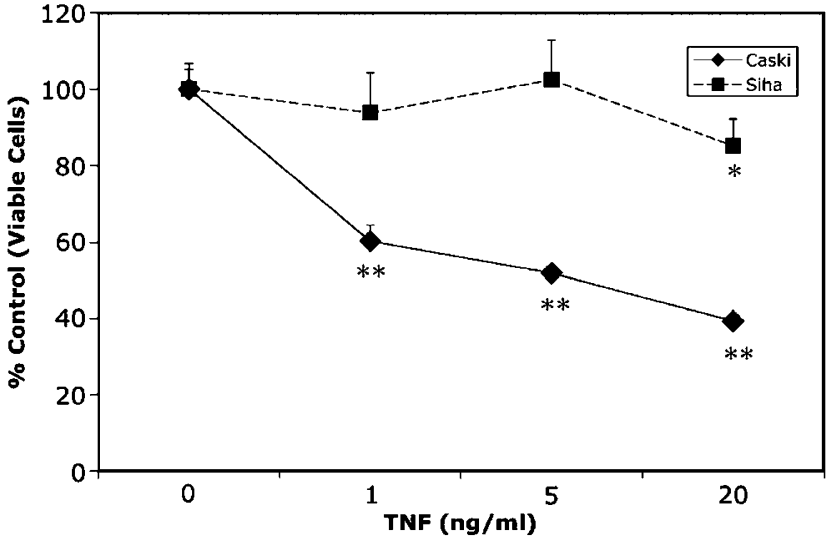

Figure 1 CaSki cells are sensitive to TNF, while SiHa cells are resistant. CaSk and $\mathrm{SiHa}$ cells were treated with either cycloheximide alone $(5 \mu \mathrm{g} / \mathrm{ml})$ or with cycloheximide plus the indicated concentrations of TNF for $16 \mathrm{~h}$, and cell survival measured by the MTT assay. Measurements were made in triplicate, and standard bars represent the standard deviation. The Student's two-tailed $t$-test was used to determine statistical significance of the differences between untreated cells and cells treated with the various concentrations of TNF, with * representing a 0.95 level of confidence and ${ }^{* *}$ representing a $>0.99$ level of confidence

cell. ${ }^{37}$ When each of these two cell lines was treated with TNF at various concentrations and analyzed for viability, the results (Figure 1) demonstrated that CaSki cells, with the higher level of HPV 16 , were quite sensitive to the cytokine, while the $\mathrm{SiHa}$ cells, with only one to two copies of the genome, were relatively resistant. These results suggested that some aspect of the high number of HPV 16 copies in the CaSki genome, such as an increased amount of one or more viral proteins, might contribute to its TNF sensitivity. However, analyzing the individual contributions of the various proteins and the amounts of these proteins in this system is complicated by the fact that multiple copies of multiple viral genes are present, and that no matched control cells, lacking HPV genetic material, are available. To examine more carefully the possible contributions of the E6 protein to this sensitization, we developed a model based on U2OS cells. U2OS cells are sensitive to TNF, Fas and TRAIL, ${ }^{16,17}$ do not contain any HPV genetic material and code for wild-type p53.

\section{Transfection of HPV 16 E6 into human cells produces both TNF-sensitive and TNF-resistant clones}

Plasmids coding for the epitope-tagged (hemagglutinin, HA) version of HPV 16 E6 in either the sense (pHA-E6 S) or antisense (pHA-E6 AS) orientation were transfected into human U2OS cells and several stable clones were isolated. After treatment with TNF for $16 \mathrm{~h}$, the cells were assayed for viability using the 3-[4,5-dimethylthiazol-2-yl]-2,5-diphenyltetrazolium bromide (MTT) assay (Figure 2a). Cells transfected with the antisense version of HA-E6, U2OSE6AS, experienced a significant loss of viability (approximately $47 \%$ viable cells remaining). Cells expressing E6, however, displayed variable responses to TNF, with some (U2OSE62, U2OSE612 and U2OSE617) experiencing protection (83, 99 and $99 \%$ viable, respectively), and others becoming more sensitive (U2OSE64a and U2OSE66, at 33 and 31\% viability, respectively). To ensure that actual cell death, rather than differential mitochondrial activation, was being recorded, a separate experiment was performed in which the individual clones were treated with TNF and cell death measured by the crystal violet assays (Figure $2 b$ ). The results from both assays were very similar, confirming the initial interpretation of cell death.

Figure 2c shows an immunoblot analysis of the expression of HA-E6 from each of the clones. Intriguingly, the cell lines showing sensitization, U2OSE64a and U2OSE66, as well as the cell line showing no change in the response to TNF, U2OSE64b, expressed the highest level of E6, while those showing protection, U2OSE62 and U2OSE612, expressed lower levels of the viral protein. No HA-E6 was detected in the immunoblot for U2OSE617, although there was clearly a significant protective effect. To determine if this cell line was expressing small amounts of HA-E6, undetectable by immunoblot, mRNA was extracted from these cells and used for reverse transcriptase-polymerase chain reaction (RTPCR) analysis. The results (Figure 2d) demonstrate that this cell line was, in fact, expressing the message for both the small and large variants of E6. ${ }^{17}$

The previous results were all obtained using selected stable clones. Stable pools were also created by transfection with HA-E6 followed by selection. These pools were then exposed to increasing levels of TNF and their viability determined by the MTT assay. The results (Figure 2e) show that although cells transfected with the antisense version of HA-E6 respond to TNF in a similar manner as do the untransfected cells, cells transfected with the sense version of HA-E6 appear sensitized to the cytokine. In this experiment, the U2OSE617 stable clone serves as a TNF-resistant control. These results suggest that under these transfection conditions, the sensitization function predominates.

One possible explanation for these results was that the resistant clones had simply decreased their level of TNF R1 expression. The results shown in Figure $2 f$ demonstrate, however, that both the TNF-resistant clones (U2OSE612, U2OSE62) and the TNF-sensitive clones (UOSE64a, U2OSE66) express TNF R1 at about the same level as do the untransfected U2OS cells.

\section{Expression of E6 results in a loss of cellular p53}

$\mathrm{E} 6$ is known to mediate the rapid degradation of $p 53,{ }^{2}$ so a p53 ELISA was used to verify the functionality of the E6 expressed in this set of clones. Each clone was treated either with vehicle alone or with the genotoxin MNNG, which causes an increase in the level of $p 53 .{ }^{38}$ Cells were then lysed and the lysates subjected to a p53 ELISA (Figure $3 a$ ). The results indicate that in all cases except that of U2OSE617, the amount of E6 expressed is sufficient to effectively eliminate all cellular p53, in either the absence or presence of genotoxic damage, while the level of p53 in U2OSE617 was approximately half of that in the untransfected cells. Given that the amount of E6 expressed in U2OSE617 was below the level of detection by immunoblot, although the message was detectable by RTPCR (Figure $2 b$ and $c$ ), these results suggest that very little E6 

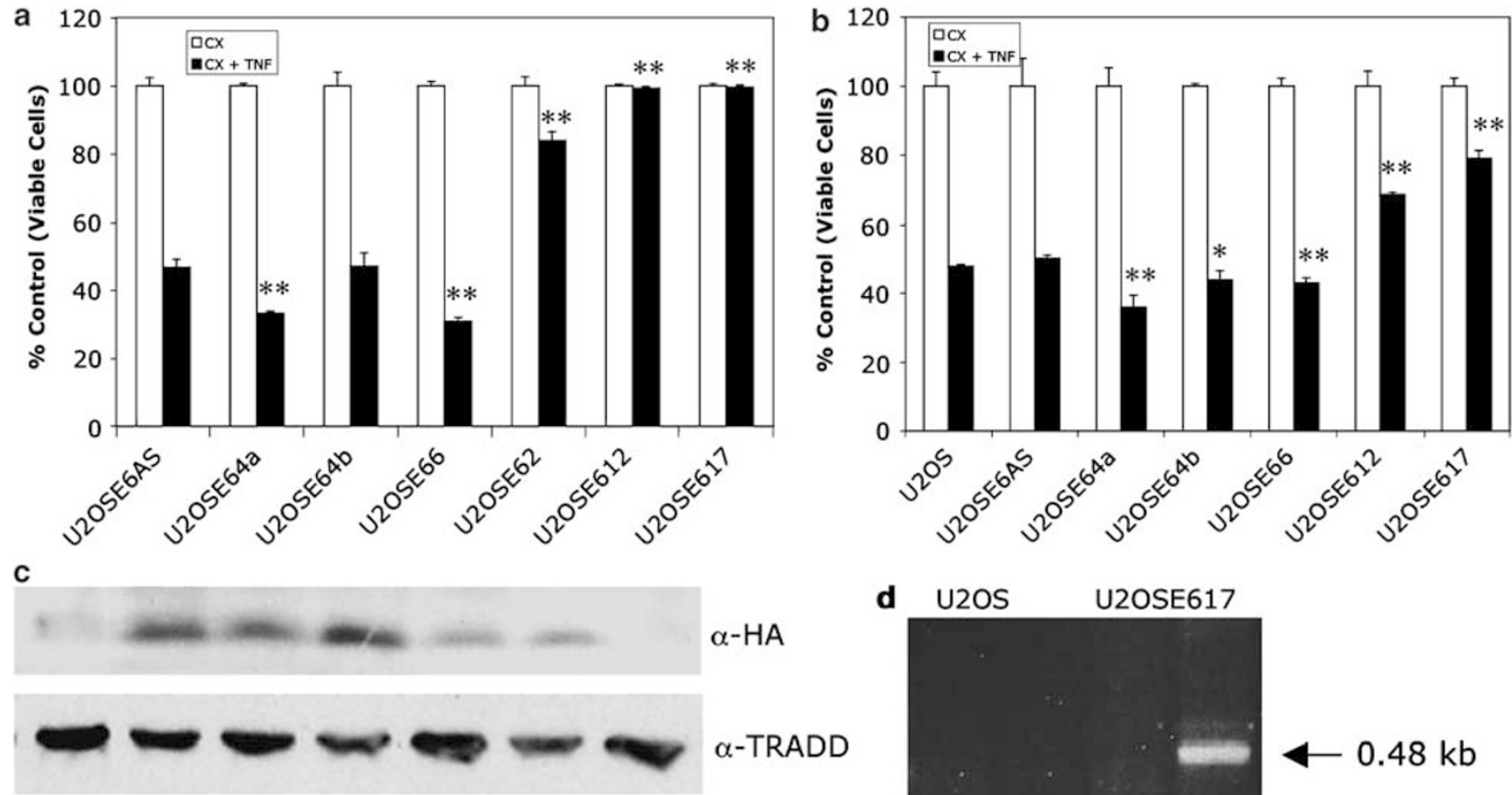

$\alpha-\mathrm{HA}$

d

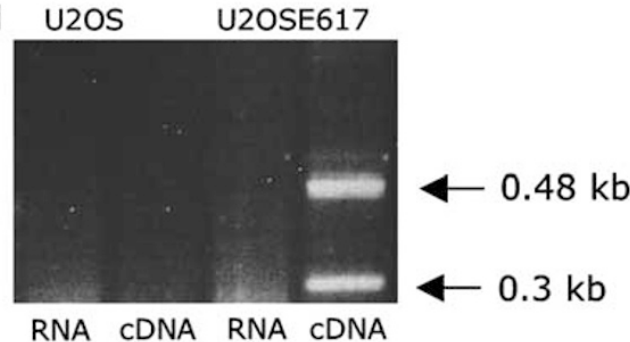

e
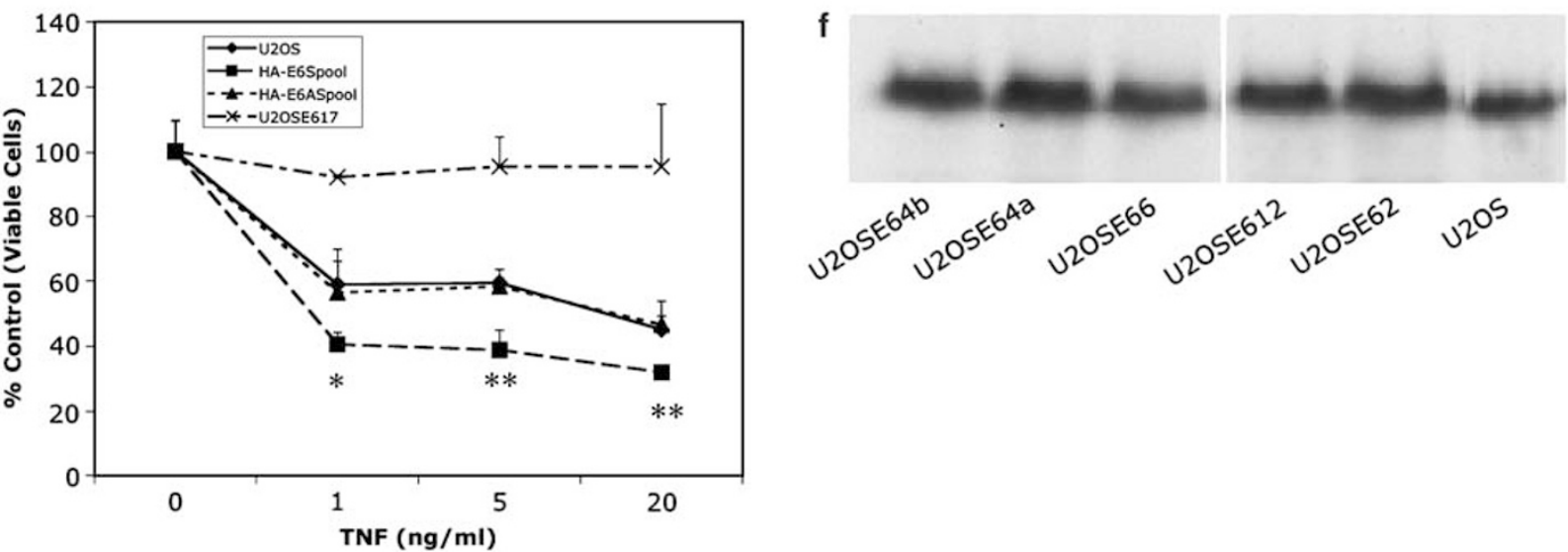

Figure 2 HPV 16 E6 can both protect cells from and sensitize cells to TNF. (a) Response of individual E6-expressing clones to TNF. U2OS cells were transfected with either the sense (U2OSE64a, U2OSE64b, U2OSE66, U2OSE62, U2OSE612, U2OSE617) or antisense (U2OSE6AS) version of HA-E6, and stable clones were selected and characterized. Both the control cells (U2OSE6AS) and the E6-expressing clones were treated with cycloheximide alone (5 $\mu \mathrm{g} / \mathrm{ml}$ ) (open bars) or with cycloheximide plus TNF $(5 \mathrm{ng} / \mathrm{ml}$ ) (closed bars). After $16 \mathrm{~h}$ of incubation, cell death was measured by the MTT assay. Measurements were made in triplicate, and the error bars represent the standard deviation. The Student's two-tailed $t$-test was used to determine statistical significance of the differences between the various TNFtreated cell lines with TNF-treated U2OSE6AS cells, with * representing a 0.95 level of confidence and ${ }^{* *}$ representing a $>0.99$ level of confidence. (b) Comparison of cell survival data as obtained by the crystal violet assay. The indicated clones were treated with cycloheximide $(5 \mu \mathrm{g} / \mathrm{ml})$ plus TNF $(5 \mathrm{ng} / \mathrm{ml})$ for $16 \mathrm{~h}$, and then their survival was assayed by the crystal violet assay. Measurements were made in triplicate, and the error bars represent the standard deviation. The Student's two-tailed $t$ test was used to determine statistical significance of the differences between the various TNF-treated cell lines and TNF-treated U2OSE6AS cells, with * representing a 0.95 level of confidence and ${ }^{* *}$ representing a $>0.99$ level of confidence. (c) Expression of HA-E6 in U2OS-derived clones. The indicated cells were lysed, and the expression of HA-E6 was detected by immunoprecipitation (top panel) using anti-HA antibodies. Input for lysates was estimated by immunoblotting using anti-TRADD (bottom panel). (d) Expression of HA-E6 in U2OSE617. Expression of HA-E6 in U2OSE617 was confirmed using RT PCR, with lanes 1 and 3 serving as negative controls for possible contamination by genomic DNA. Arrows indicate the expected migration position of the indicated products. (e) Response of pooled E6-expressing cells to TNF. U2OS cells were transfected with the indicated plasmids and subjected to selection with G418. The resulting stable pools were treated with cycloheximide $(5 \mu \mathrm{g} / \mathrm{ml})$ and with the indicated concentrations of TNF. After incubation for $16 \mathrm{~h}$, cell viability was measured by the MTT assay. Measurements were made in triplicate, and the error bars represent the standard deviation. The Student's one-tailed t-test was used to determine statistical significance of the differences between cells transfected with the HS-E6 construct and cells transfected with the HA-E6AS construct, with * representing a 0.95 level of confidence and ${ }^{* *}$ representing a $>0.99$ level of confidence. (f) TNF R1 expression in E6-expressing cell lines. Cells were lysed and $45 \mu \mathrm{g}$ of total protein was subjected to SDS-PAGE. Detection of TNF R1 was performed by immunoblot using antibodies directed against TNF R1 
is needed to mediate the rapid degradation of even increased, genotoxin-induced amounts of p53. To confirm these results, the parental U2OS cells and the sensitive clone U2OSE64a were treated with a second genotoxin, mitomycin $\mathrm{C}$. The cells were then lysed and analyzed for the presence of p53 by immunoblot (Figure $3 \mathrm{~b}$ ), with the results confirming a loss of p53 in the E6-expressing cells. Together, these findings demonstrate that the E6 expressed in each of the clones, sensitive as well as resistant, is functional, and support the idea that in clone U2OSE617, a very low but functional amount of E6 is present. This amount is sufficient to completely protect cells from TNF, but is able to mediate the degradation of only about half of the induced levels of cellular p53.

\section{Sensitive clones, as well as untransfected cells, undergo apoptosis following TNF treatment}

It has been reported ${ }^{39,40}$ that following engagement of an apoptosis inducer with its receptor, cells can become necrotic if the apoptotic pathway is blocked. To examine whether this phenomenon could account for the differing responses of the clones to TNF, U2OS and the TNF-sensitive U2OSE6 6 cells were each treated with cycloheximide and TNF for variable times, fixed and stained with DAPI, and their morphology examined microscopically (Figure 4). Cells were considered apoptotic if they exhibited nuclear condensation, a loss of a

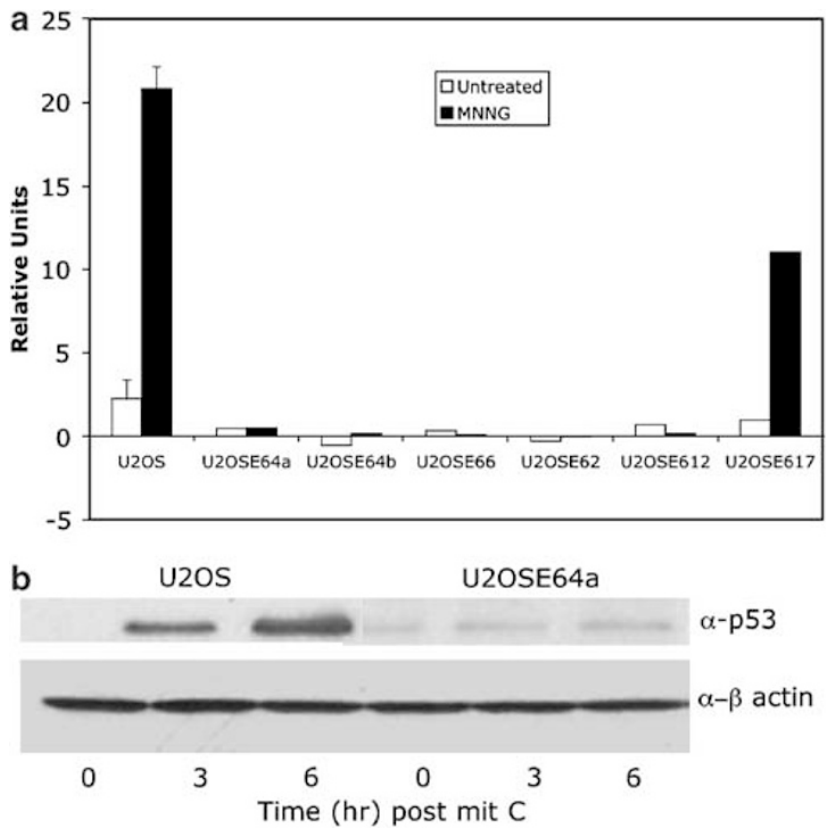

Figure 3 Transfected HA-E6 retains biological activity in both sensitive and resistant clones. (a) ELISA measurement of baseline and induced levels of p53 in E6-expressing clones. The p53 ELISA was used to measure the amount of p53 in the indicated clones both before and after a $4 \mathrm{~h}$ treatment with the genotoxin MNNG $(10 \mu \mathrm{g} / \mathrm{ml})$. Error bars represent the standard deviation. (b) Immunoblot measurement of baseline and induced levels of p53 in U2OS and U2OSE64a cells. U2OS and U2OSE64a cells were treated with the genotoxin mitomycin C for the indicated times. Lysates were prepared, subjected to SDS-PAGE and transferred to a membrane, and then immunoblotted with antibodies directed against p53 (DO-7) (top panel) or anti- $\beta$-actin (bottom panel) regular nuclear shape and/or nuclear fragmentation. Usually, this process coincided with a loss of the regular shape of the cell, the appearance of extensions and protrusions, and/or blebbing of the cell surface. In both the parental U2OS and the E6-expressing U2OSE66 cells, very low levels of apoptosis were observed prior to TNF treatment $(0.5$ and $1.0 \%$, respectively). By $2 \mathrm{~h}$, the level of apoptosis in U2OS was still very low $(1.0 \%)$, while some apoptotic cells were appearing in the U2OSE66 culture (4.8\%). By $4 \mathrm{~h}$, both cell lines were undergoing measurable apoptosis $(16.5 \%$ in U2OS cells as compared to $20.0 \%$ in U2OSE66 cells), and by $6 \mathrm{~h}, 16.7 \%$ of U2OS cells were apoptotic while $41.0 \%$ of U2OSE66 cells were apoptotic.

To confirm these morphological results, the expected consequences of engagement of the apoptotic pathway were analyzed at a more molecular level by examining the cleavage fragments produced for lamin B, PARP and topoisomerase I (Topo I). U2OS and U2OSE6 cells were treated with cycloheximide and TNF for various times and then lysed. Lysates were then separated by SDS-PAGE and subjected to immunoblot analysis using antibodies directed against lamin B, PARP and Topo I. During apoptosis (such as that induced by staurosporine, STS), lamin B was cleaved into a fragment of approximately $46 \mathrm{kDa}, \mathrm{PARP}$ into a fragment of $89 \mathrm{kDa}$ and Topo I into a fragment of $70 \mathrm{kDa}$ (Figure $5 \mathrm{~b}) .{ }^{41,42}$ In contrast, necrosis (induced by tert-butyl hydroperoxide, $\mathrm{TBH}$ ) did not induce the appearance of the apoptotic fragments for lamin B and PARP. In the case of Topo I, a signature necrotic fragment of $45 \mathrm{kDa}$ was detected, consistent with previous reports demonstrating that the generation of this fragment is a distinctive feature of necrotic cell death. ${ }^{42,43}$ The pattern of
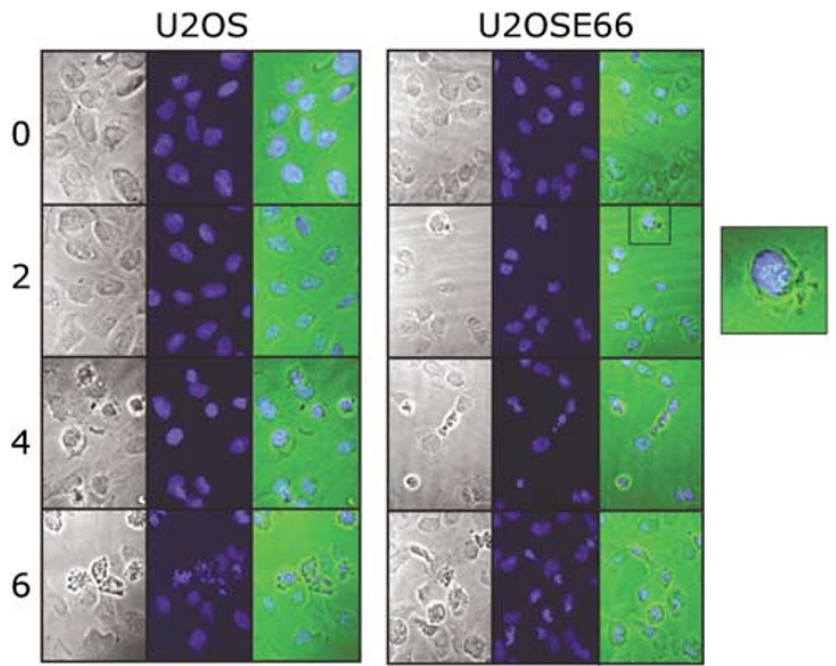

Figure 4 E6-expressing and control cells die by apoptosis - morphology. U2OS and U2OSE66 cells were seeded on coverslips in six-well plates and treated with TNF $(5 \mathrm{ng} / \mathrm{ml})$ plus cycloheximide $(5 \mu \mathrm{g} / \mathrm{ml})$ for $0,2,4$ or $6 \mathrm{~h}$. After fixation in $4 \%$ paraformaldehyde, the slips were mounted using Vectashield mounting media with DAPI. Morphology of cells was analyzed by phase-contrast microscopy, and the DAPI-stained nuclei monitored using a UPA1FI objective. For each set of three panels, the left represents phase-contrast microscopy, the middle the DAPI staining pattern and the right a merged image. The green background in the merged image is due to the light used to obtain a visible image. The enlarged image to the right is another photograph of the outlined cell (U2OSE66, $2 \mathrm{~h}$, merged image) 
cleavage fragments detected in both cell lines from all three substrates, lamin B, PARP and Topo I (Figure 5a), defines an apoptotic form of cell death for both U2OS and U2OSE66 cells. These results rule out a simple switch from apoptosis to necrosis as an explanation for the observed sensitization. However, it should also be noted that cleavage to the apoptotic fragments occurs earlier in the TNF-sensitive line (U2OSAE66) than in the untransfected cells (U2OS), consistent with the morphological results described above (Figure 4).

\section{TNF-induced cell death is caspase dependent}

One hallmark of apoptosis is its dependence on caspase activation. Therefore, if cells respond to TNF by undergoing apoptosis, as indicated by the previous experiments, they should experience protection in the presence of an agent that blocks caspase activation, such as Z-VAD-FMK. To test this prediction, each of the indicated clones was treated with cycloheximide and TNF in either the presence or absence of Z-VAD-FMK for $16 \mathrm{~h}$ and assayed for viability using the MTT assay. The results (Figure 6) demonstrate that Z-VAD treatment provided the untransfected parental cells (U2OS), control cells transfected with the antisense version of E6

a
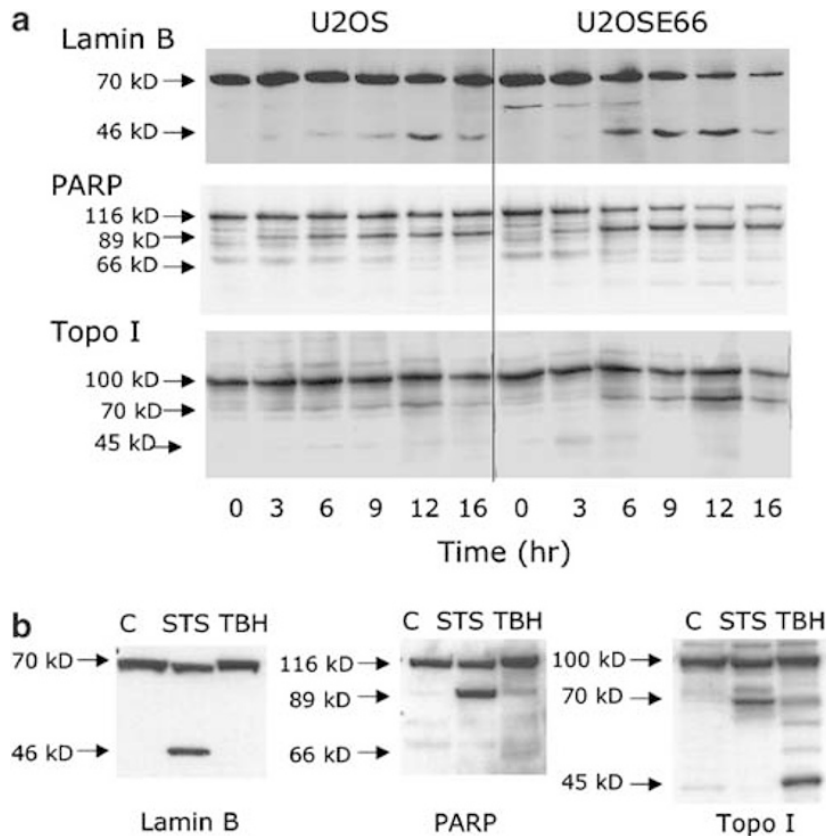

Figure 5 E6-expressing and control cells die by apoptosis - cleavage patterns (a) Cleavage of lamin B, PARP and Topo I in U2OS and U2OSE66 cells treated with TNF. U2OS and U2OSE66 cells were treated with TNF $(5 \mathrm{ng} / \mathrm{ml})$ in the presence of cycloheximide $(5 \mu \mathrm{g} / \mathrm{ml})$ for the indicated times. Lysates were prepared, and equal amounts ( $50 \mu \mathrm{g}$ total protein) were subjected to SDSPAGE, transferred to a membrane and then immunoblotted with antibodies directed against lamin B (top panel), PARP (middle panel) or Topo I (bottom panel). (b) Cleavage patterns seen during apoptosis and necrosis. U2OS cells were either untreated (C), treated for $6 \mathrm{~h}$ with STS $(4 \mu \mathrm{M})$, which induces apoptosis, or treated for $6 \mathrm{~h}$ with TBH $(250 \mu \mathrm{M})$, which induces necrosis. Cells were lysed and equal amounts of total cellular protein $(50 \mu \mathrm{g})$ were separated by SDS-PAGE, transferred to a membrane and then immunoblotted with antibodies directed against lamin B (left panel), PARP (middle panel) or Topo I (right panel)
(U2OSE6AS) and cells sensitized by E6 (U2OSE66, U2OSE64a or U2OSE64b) with protection from TNF, with the degree of protection greatest in cells that were otherwise the most sensitive to TNF. The two cell lines earlier shown to be resistant to TNF, U2OSE612 and U2OSE617, experienced less protection, presumably because they were already well protected from TNF. These results provide strong evidence that the cell death noted in these cells is caspase dependent and apoptotic in nature.

\section{Caspases 3 and 8 are activated following TNF treatment of sensitive cells}

To further confirm the apoptotic nature of the cell death observed in the sensitive cells, U2OSE6AS (antisense version of HA-E6), U2OSE66 (sensitive) and U2OSE612 (resistant) cells were treated with TNF and the activation of caspases 3 and 8 measured in cell lysates using a commercially available fluorigenic assay. The results demonstrate that caspase 3 is activated by approximately $4.5 \mathrm{~h}$ in both U2OSE6AS and U2OSE66 cells (Figure 7a). No significant increase in caspase 3 was detected in the resistant cells, U2OSE612, during the time course of this assay. The results for caspase 8 (Figure $7 \mathrm{~b}$ ) also show induction for both the U2OSE6AS cells and the U2OSE66 cells, with the induction in U2OSE66 cells occurring earlier and to a greater extent than in the U2OSE6AS cells. In this assay, as in the caspase 3 assay, no significant induction was seen for the TNF-resistant U2OSE612 cells. These results demonstrate that in both the control cells and in the sensitive U2OSE66 cells, TNF treatment triggers an apoptotic pathway that includes the activation of both caspases 3 and 8 .

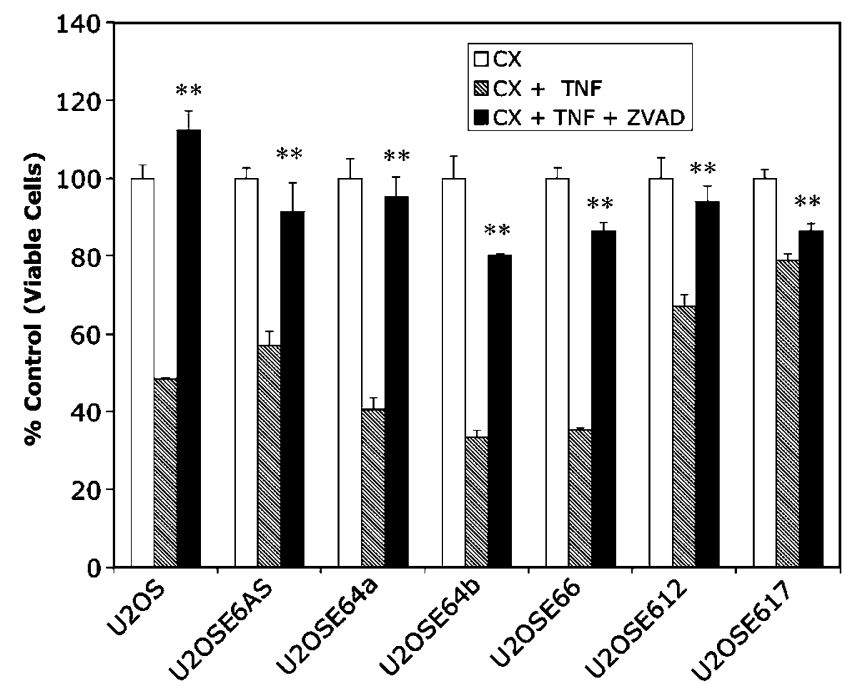

Figure 6 TNF-triggered cell death is caspase dependent. The indicated cells were treated with cycloheximide $(5 \mu \mathrm{g} / \mathrm{ml})$ or cycloheximide plus TNF $(5 \mathrm{ng} / \mathrm{ml})$ in the presence or absence of Z-VAD-FMK $(10 \mu \mathrm{M})$, and cell death measured by the MTT assay. Measurements were made in triplicate, and the error bars represent the standard deviation. The Student's one-tailed test was used to determine statistical significance of the difference between cells treated and untreated with Z-VAD-FMK, with ** representing a $>0.99$ level of confidence 


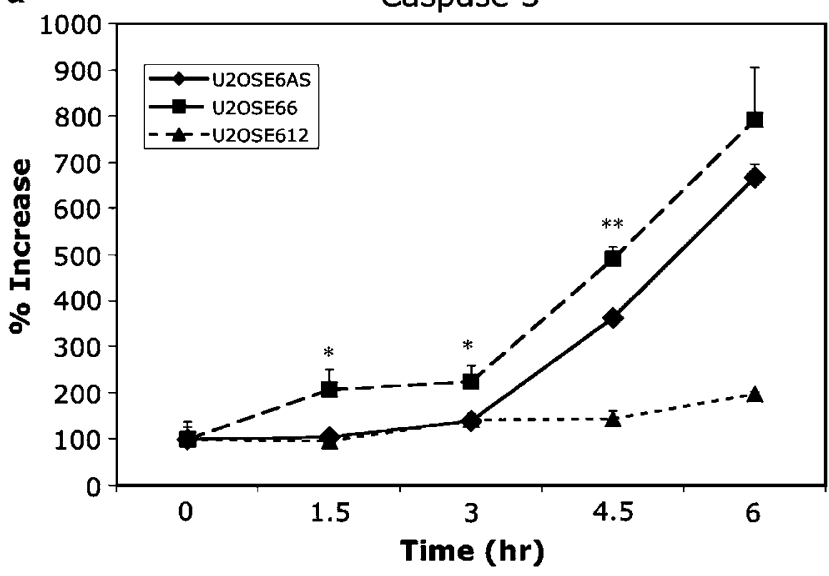

b

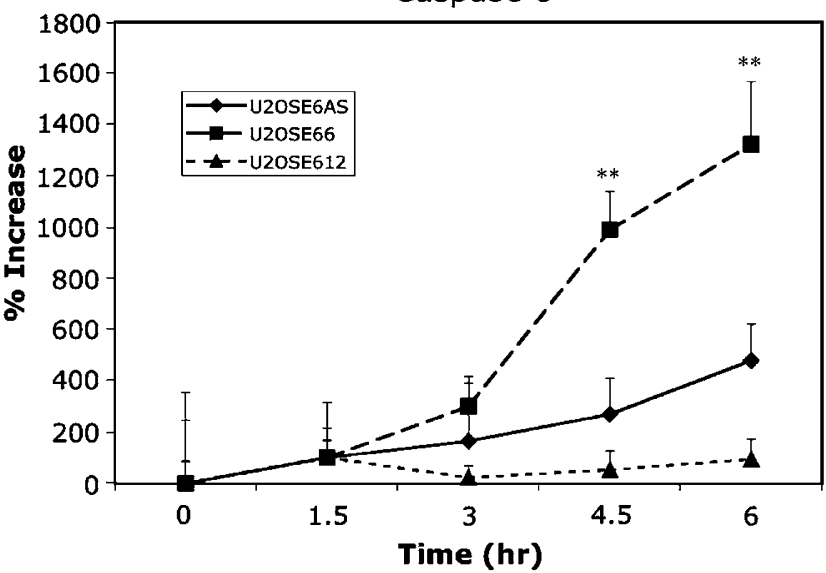

Figure 7 Caspase 3 and caspase 8 activities following TNF treatment are enhanced in TNF-sensitive and repressed in TNF-resistant cells. (a) Caspase 3 activity. U2OSE6AS (coding for the antisense version of HA-E6), U2OSE66 (E6expressing, TNF-sensitive) and U2OSE612 (E6-expressing, TNF-resistant) cells were treated with TNF $(5 \mathrm{ng} / \mathrm{ml})$ in the presence of cycloheximide $(5 \mu \mathrm{g} / \mathrm{ml})$ for the times indicated and then lysed. Lysates were analyzed for caspase 3 activity using DEVD-AMC as the substrate in the presence and absence of the caspase 3 inhibitor DEVD-CHO. The activity in wells containing the inhibitor was subtracted from that in wells lacking the inhibitor. Activity is expressed as the percentage of caspase activity in untreated U2OSE6AS cells. Each time point was measured in triplicate, and error bars represent the standard deviation. The Student's onetailed $t$-test was used to determine statistical significance of the differences between U2OSE6AS and U2OSE66 cells, with * representing a 0.95 level of confidence. (b) U2OSE6AS, U2OSE66 and U2OSE612 cells were treated and lysed as described in (a) and then analyzed for caspase 8 activity using IETDAMC as the substrate in the presence and absence of the caspase 8 inhibito IETD-CHO. Data were analyzed as in (a), with the exception that values were normalized to the value of U2OSE6AS cells at $1.5 \mathrm{~h}$ rather than at $0 \mathrm{~h}$. The Student's one-tailed $t$-test was used to determine statistical significance of the differences between U2OSE6AS and U2OSE66 cells, with * representing a 0.95 level of confidence

\section{HPV E6 does not affect cell death mediated through the mitochondrial pathway in either sensitive or resistant clones}

Apoptosis induced by way of surface receptors can proceed with or without significant participation of the mitochondrial pathway, depending on the cellular context. ${ }^{44,45}$ Mitochondria have also been implicated in necrotic forms of cell death. To determine whether mitochondrial participation was important for TNF-mediated cell death in our system, cells were treated with cyclosporine A concurrent with TNF exposure. Cyclosporine $\mathrm{A}$ has been thought to inhibit mitochondrial-mediated cell death by blocking mitochondrial megachannel formation, ${ }^{46-49}$ and recent reports ${ }^{50,51}$ using cyclophilin D knockout mice suggest that cyclosporine treatment may inhibit necrotic as opposed to apoptotic cell death. The results (Figure 8a) show clearly that in no case did cyclosporine A treatment provide protection to cells from TNF, indicating that the mitochondrial pathway does not play a major role in TNFinduced cell death of U2OS-derived cells. These results also allow the conclusion that E6 acts at steps of the pathway other than those that involve mitochondria, and suggest that the presence or absence of E6 might have no effect on cell death triggered by inducers of the mitochondrial pathway.

To determine if this were indeed the case, both sensitive and resistant clones were treated with either ceramide or the genotoxin MNNG, which are thought to signal for apoptosis through the mitochondrial pathway (see Yang and DuerksenHughes $^{52}$ and Obeid et $a l^{53}$ and references therein). The results demonstrate that all treated cells readily underwent cell death following treatment with either ceramide (Figure $8 b$ ) or MNNG (Figure 8c). This response was independent of the amount of E6 expressed, in that cells expressing no E6 or low, medium or high levels of the viral protein all responded in an equivalent manner. There was also no relationship between the response of cells to TNF and their response to either ceramide or MNNG. Therefore, E6 is not acting at the level of the mitochondrial or downstream parts of the apoptotic pathway either to sensitize or to protect cells from TNF.

\section{The response of E6-expressing clones to TNF R1 reflects their response to TNF}

The TNF-mediated apoptotic response can frequently be mimicked by the transfection of TNF R1 into cells, and we have previously shown that $\mathrm{E} 6$ can protect cells from apoptosis induced in this manner. ${ }^{16}$ To determine whether the level of E6 affects the cellular response to TNF R1, U2OS cells as well as clones both sensitive and resistant to TNF were transfected with the death domain of TNF R1 and analyzed for cell death $48 \mathrm{~h}$ later. In this experiment, cells transfected with a truncated, inactive version of the TNF R1 serve as controls, as we have previously shown that this form does not bind to E6. ${ }^{16}$ The results (Figure 9) show that the pattern of the cellular response to transfection with TNF R1 is similar to that seen following treatment by TNF (compare to Figure 2a), although the level of protection observed for U2OSE617 is less, suggesting that the lower amount of E6 expressed in these cells is insufficient to protect them from the relatively high level of TNF R1 DD produced following transient transfection. These findings therefore support a model in which E6 acts through the TNF/ TNF R1 pathway, but not through the mitochondrial pathway, either to sensitize or to protect cells.

\section{Low levels of E6 protect cells from TNF, whereas high levels cause sensitization}

The results described thus far suggest, but do not prove, that low levels of E6 are protective while high levels are 
a

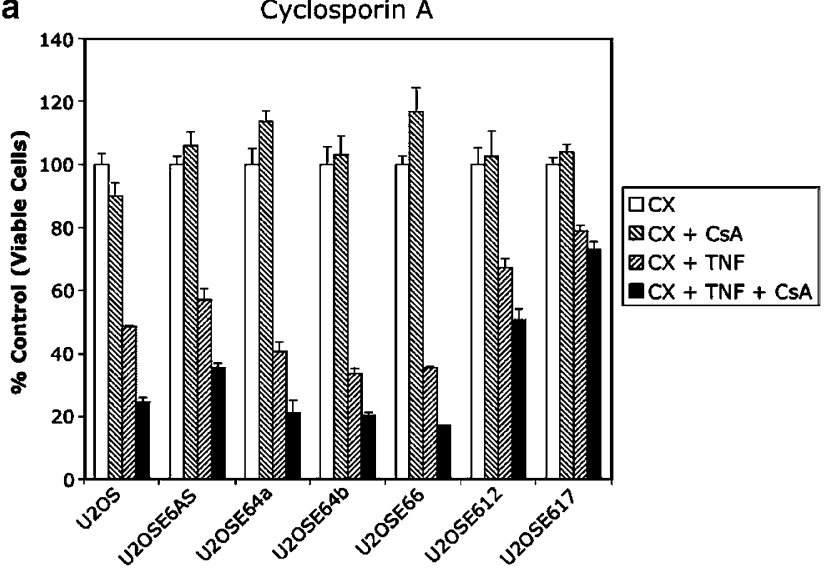

b
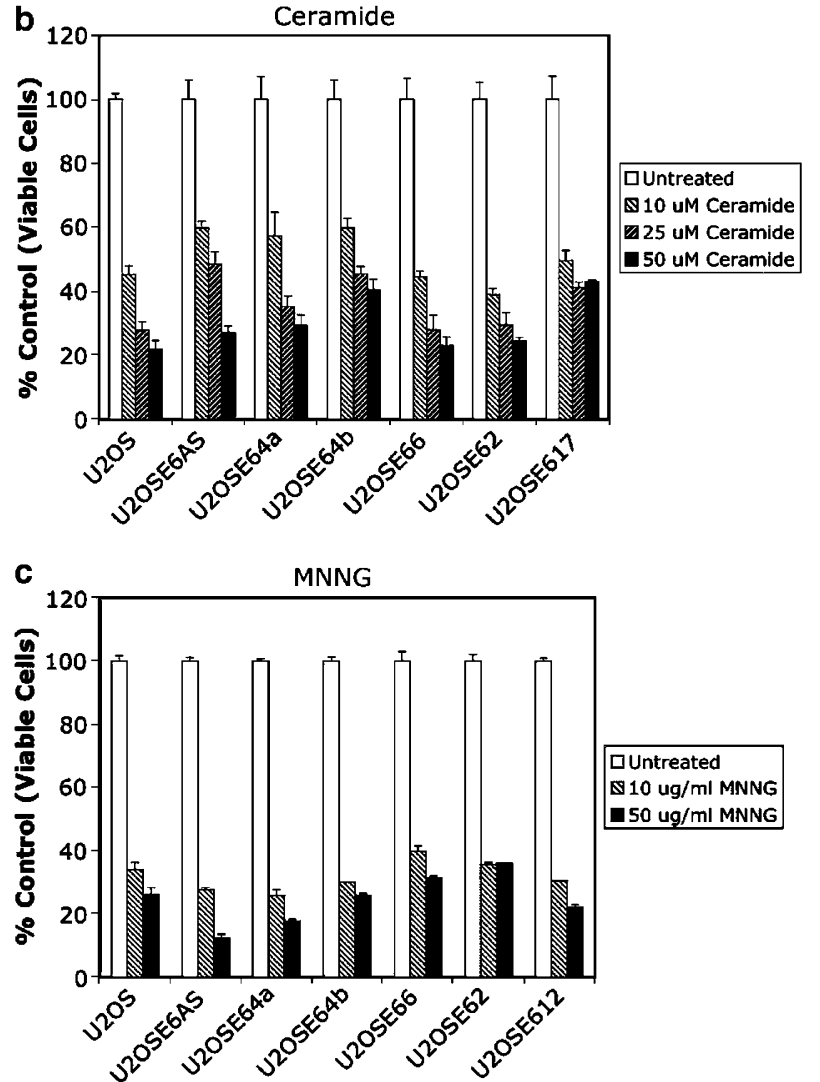

Figure 8 HA-E6 does not block the mitochondrial cell death pathway. (a) Mitochondrially mediated cell death does not play a major role in TNF-triggered cell death in U2OS-derived cells. Untransfected U2OS or cells transfected with the antisense (U2OSE6AS) or sense versions of E6 were treated with cycloheximide $(5 \mu \mathrm{g} / \mathrm{ml})$, cycloheximide plus cyclosporine A $(50 \mu \mathrm{M})$, cycloheximide plus TNF $(5 \mathrm{ng} / \mathrm{ml})$ or cycloheximide, cyclosporine A and TNF for $16 \mathrm{~h}$. Cell viability was measured by the MTT assay. Each measurement was performed in triplicate, and error bars indicate the standard deviation. (b, c) Untransfected U2OS cells or cells transfected with the antisense (U2OSE6AS) or sense versions of $E 6$ were treated with either ceramide $(10,25$ or $50 \mu \mathrm{M})(\mathbf{b})$ or MNNG (10 or $50 \mu \mathrm{g} / \mathrm{ml}$ ) (c) for 24 or $16 \mathrm{~h}$, respectively. Cell viability was measured using the MTT assay. Each measurement was performed in triplicate, and error bars indicate the standard deviation

sensitizing. Comparisons between the levels of E6 in each cell line, as measured by immunoblot, with a biological activity are complicated by the fact that each clone represents a separate

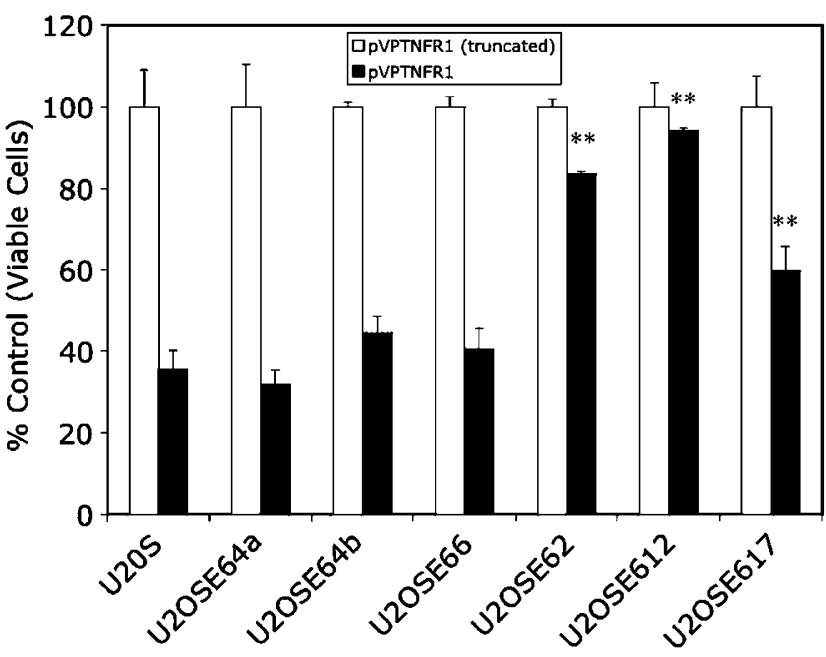

Figure 9 HA-E6 inhibits TNF R1-induced cell death in TNF-resistant but not in TNF-sensitive cells. Untransfected (U2OS) or E6-expressing cells were transiently transfected with plasmids encoding either the complete TNF R1 death domain (TNF R1 DD) or a truncated version of the TNF R1 death domain that lacks the C-terminal 41 amino acids (TNF R1 $\Delta$ DD). After incubation for $48 \mathrm{~h}$, the percentage of viable cells was measured by the MTT assay. Measurements were made in triplicate, and the error bars represent the standard deviation. The Student's two-tailed $t$-test was used to determine statistical significance of the differences between the various TNF-treated cell lines and TNF-treated U2OS cells, with * representing a 0.95 level of confidence and ** representing a $>0.99$ level of confidence

integration event with variable cellular genes being disrupted and each introduced gene present in a different cellular regulatory environment. To address the question of dose effects more carefully, we created two cell lines in which the level of E6 expressed is regulated by the amount of doxycycline (dox) or tetracycline present in the culture media (ClonTech TetOff system) $^{17}$ (Figure 10a). For both cell lines, the immunoblot (top two panels) shows a large amount of E6 produced in the absence of dox that gradually decreases as the amount of dox present in the culture medium rises, such that HA-E6 becomes undetectable by a level of $4 \mathrm{ng} / \mathrm{ml}$ dox. Meanwhile, an immunoblot using antibodies directed against $\beta$-actin, loading amounts of lysate corresponding to the immunoprecipitation input of the top two panels in Figure $10 a$, showed no change (third panel). The bottom panel of Figure 10a shows an RT-PCR analysis of the E6 message in U2OSE6tet24 as expressed in the presence of different concentrations of dox. Even at $200 \mathrm{ng} / \mathrm{ml}$ dox, where no E6 was detectable by immunoblot, message for both the large and small transcripts of $\mathrm{E} 6$ is produced and is easily detectable. As expected, the amount of E6 message then increases as the level of dox decreases and the level of E6 correspondingly rises.

U2OSE6tet24 cells grown in the presence of variable amounts of dox (and therefore producing variable amounts of E6) were then treated with $5 \mathrm{ng} / \mathrm{ml}$ TNF and their viability measured by the MTT assay (Figure 10b). In this experiment, the untransfected U2OS cells served as controls (far left data points), responding to TNF treatment with approximately a $50 \%$ loss of viability. At high levels of dox $(6 \mathrm{ng} / \mathrm{ml})$, low levels of E6 were produced and the cells were protected $(76 \%$ viability for the U2OSE6tet24 cells and $65 \%$ for the 

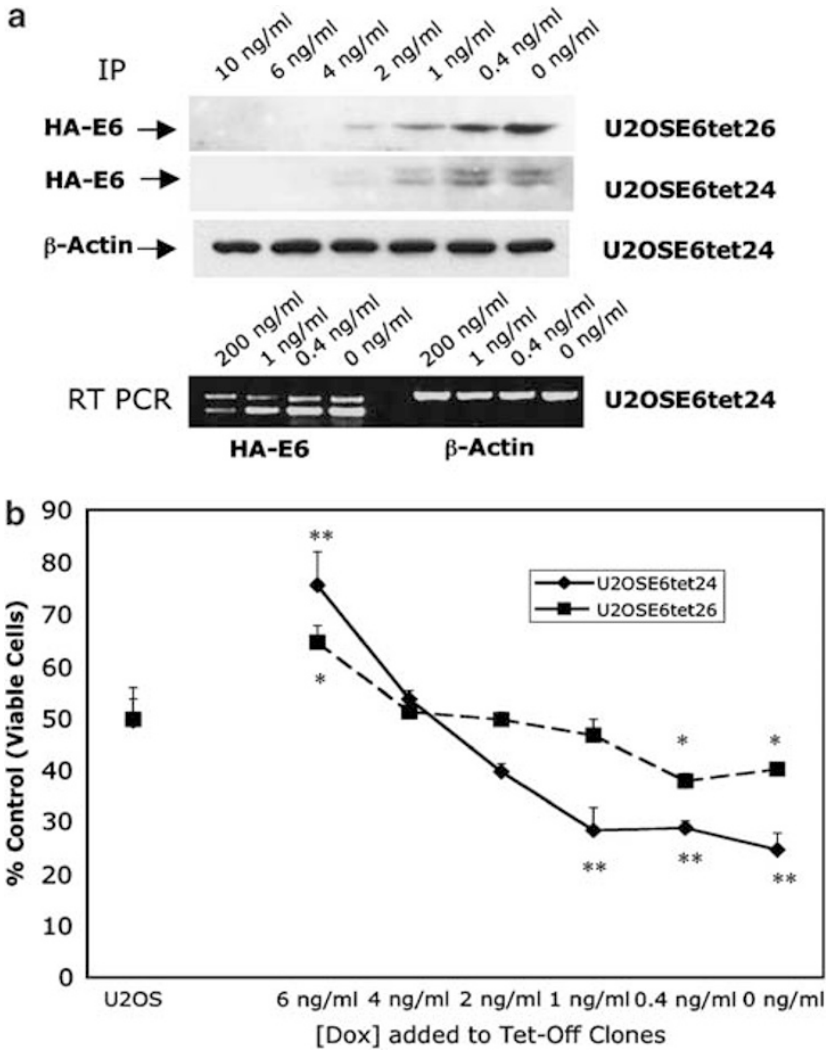

Figure 10 The response of E6-expressing cells to TNF is dose dependent. (a) U2OS cells stably transfected with HA-E6 express variable amounts of the protein and message as regulated by the amount of dox present in the culture media. U2OSE626 (top panel) or U2OSE624 cells (second, third and fourth panels) were cultured in the presence of the indicated concentrations of dox, and then the amount of HA-E6 protein (top two panels, $\beta$-actin protein (third panel), HA-E6 message and $\beta$-actin message (fourth panel) was measured. HA-E6 protein levels were analyzed by immunoprecipitation followed by immunoblot using polyclonal anti-HA (rat, peroxidase conjugated) (top two panels). The input amounts for immunoprecipitation were equivalent as shown by the immunoblot of $\beta$-actin ( $15 \mu \mathrm{g}$ total protein/lane). Message levels were analyzed by RT-PCR (fourth panels). (b) Low levels of E6 expression protect cells from TNF, while high levels of E6 expression sensitize cells to TNF. Cells stably transfected with HAE6 under the control of the tet-responsive element were cultured in the presence of the indicated concentrations of dox, and then treated with TNF $(5 \mathrm{ng} / \mathrm{ml})$ in the presence of cycloheximide $(5 \mu \mathrm{g} / \mathrm{ml})$ for $16 \mathrm{~h}$. The untransfected, control U2OS cells were also treated with TNF and cycloheximide. Viability was measured using the MTT assay. Each measurement was performed in triplicate, and error bars indicate the standard deviation. The Student's two-tailed $t$-test was used to determine statistical significance of the differences between the tet-responsive cells in different culture conditions and the U2OS cells, with * representing a 0.95 level of confidence and ${ }^{* *}$ representing a $>0.99$ level of confidence

U2OSE6tet26 cells). As the level of dox decreased, the cells became increasingly more sensitive to TNF, with the cells grown in the complete absence of the drug $(0 \mathrm{ng} / \mathrm{ml})$ and thus producing the maximal amount of E6 significantly more sensitive to TNF than were the untransfected cells (approximately $24 \%$ of the U2OSE6tet24 cells and $40 \%$ of the U2OSE6tet26 cells viable). Similar findings were obtained when both higher $(25 \mathrm{ng} / \mathrm{ml})$ and lower $(2.5 \mathrm{ng} / \mathrm{ml})$ concentrations of TNF were used (data not shown). These results demonstrate clearly that while low levels of E6 protect cells from TNF, high levels sensitize them to the cytokine, providing evidence of opposing effects by the same protein in the same cell line with the dose of $\mathrm{E} 6$ determining the cellular response.

\section{The effect of E6 dose on the cellular response to TNF is opposite to its effect on the cellular response to Fas}

Our previous results ${ }^{17}$ have shown clearly that the HPV 16 E6 protein can protect cells from Fas-mediated apoptosis, with higher levels of E6 providing greater protection. The opposite has been shown in this study for TNF, where low levels of E6 provide protection and high levels cause sensitization. The experiment shown in Figure 11 summarizes this comparison. Here, cells were grown in the presence of variable amounts of dox, and then treated with either TNF or anti-Fas and analyzed for viability. Under these experimental conditions, the untransfected U2OS cells are approximately $50 \%$ viable when treated with $5 \mathrm{ng} / \mathrm{ml} \mathrm{TNF}$, or $40 \%$ viable following treatment with $10 \mathrm{ng} / \mathrm{ml}$ anti-Fas. At the low levels of E6 produced in the presence of $100 \mathrm{ng} / \mathrm{ml}$ dox, the tet-regulated cells experience significant protection from TNF treatment (approximately $65 \%$ viable), while a reduced, although still significant, amount of protection is seen following exposure to anti-Fas. These results remain essentially the same for the amounts of E6 produced by 10 and $6 \mathrm{ng} / \mathrm{ml}$ levels of dox. However, with lower levels of dox (4 and $1 \mathrm{ng} / \mathrm{ml}$ ) and the correspondingly higher levels of E6, cells become increasingly sensitive to TNF (to $35 \%$ viability at $1 \mathrm{ng} / \mathrm{ml}$ dox,) and increasingly resistant to anti-Fas $(80 \%$ viability at $1 \mathrm{ng} / \mathrm{ml}$ dox).

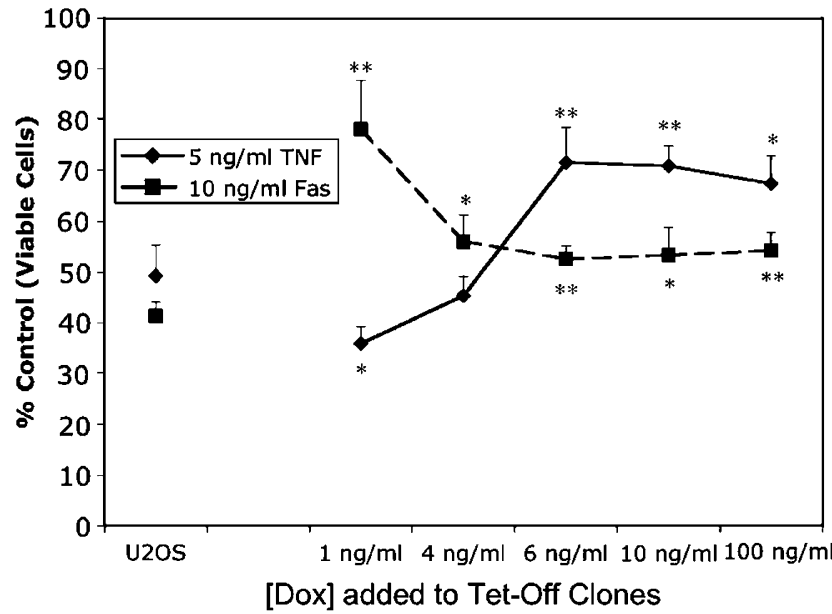

Figure 11 Low and high levels of E6 have opposing effects on cellular responses to TNF and to Fas. Cells stably transfected with HA-E6 under the control of the tet-responsive element were cultured in the presence of the indicated concentrations of dox and were treated with TNF $(5 \mathrm{ng} / \mathrm{ml})$ or anti-Fas $(10 \mathrm{ng} / \mathrm{ml})$ in the presence of cycloheximide $(5 \mu \mathrm{g} / \mathrm{ml})$ for $16 \mathrm{~h}$. As a control, U2OS cells were also treated with TNF and anti-Fas. Viability was measured using the MTT assay. Each measurement was performed in triplicate, and error bars indicate the standard deviation of the mean. The Student's two-tailed $t$-test was used to determine statistical significance of the differences between the tetresponsive cells in different culture conditions and the U2OS cells, with * representing a 0.95 level of confidence and ${ }^{*}$ representing a $>0.99$ level of confidence 


\section{Discussion}

To survive and propagate, viruses have developed numerous means by which to modulate the host immune system, including those mechanisms designed to cause apoptosis in virus-infected cells, and a review of the related works is available in the literature. ${ }^{31,32,54-57}$ While most attention has focused on viral proteins that inhibit apoptosis, there are also examples of viral proteins that cause or potentiate apoptosis. In some cases, this is likely an unintentional consequence of other necessary activities of the virus (for example, the upregulation of DNA synthesis by the adenovirus E1A protein ${ }^{58}$ ), although in others, it may actually enhance viral propagation.

Several viruses and their proteins have targeted the first few steps in the TNF apoptotic pathway. These include the Epstein-Barr virus BZLF1 protein, which downregulates expression of TNF R1; ${ }^{59}$ the Epstein-Barr virus LMP1 protein, which binds to TRAFs and to TRADD; ${ }^{60}$ the human cytomegalovirus, which downregulates TNF $\mathrm{R} 1 ;{ }^{61}$ the herpesvirus 2 E8 protein, which interacts with the caspase 8 prodomain; the molluscum contagiosum virus MC159 protein, which interacts with FADD; ${ }^{62-64}$ and the HPV 16 E6 protein, ${ }^{16,17}$ which binds to both the TNF R1 and to FADD. Interestingly, a bacterial protein, the Chlamydia trachomatis CADD protein acts in a similar manner by interacting with the death domains of TNF R1, Fas, DR4 and DR5. ${ }^{65}$ Such examples demonstrate the importance to the virus or bacteria of being able to manipulate this host pathway.

The work reported here demonstrates that the HPV 16 E6 protein can both sensitize and protect cells from TNF, depending on the level of E6 expressed. With regard to the protective function, clone U2OSE617 may be of particular interest. This clone expressed very low levels of E6 (undetectable by immunoblot, the message detectable by RT-PCR, and causing degradation of only half of the induced level of cellular p53), yet provided complete protection from TNF, suggesting that E6 can provide protection from TNF at much lower concentrations than are required for p53 degradation.

Sensitized clones, like the parental cells, undergo apoptosis rather than necrosis as defined by several criteria. The morphology of the dying cells shows condensed chromatin and/or fragmentation as well as cytoplasmic blebbing; cleavage of substrates such as lamin B, PARP and Topo I follows the apoptotic rather than the necrotic pattern; cell death is caspase dependent; and robust activation of caspases 3 and 8 was detected. Compared to untransfected cells, the sensitized cells demonstrate an earlier activation of caspase 8 , earlier morphological changes and an earlier cleavage of cellular substrates following TNF treatment. Cyclosporine A treatment did not provide protection from TNF, indicating a lack of major mitochondrial involvement in this particular death pathway, and expression of either high or low levels of E6 had no effect on cell death mediated through the mitochondrial pathway. Furthermore, the pattern of the cellular response to transfected TNF R1 reflects the response to TNF treatment. These results support a model in which both the protective and sensitizing functions of E6 reflect events that occur at or downstream of TNF R1 and at or upstream of caspase 3 activation.
Treatment of the inducible cell lines U2OSE6tet24 and U2OSE6tet26 with TNF led to the conclusion that it is the dose of E6 that determines its effect, sensitizing or protective, on expressing cells. To the best of our knowledge, this is the first demonstration that a virus protein can modulate a host response in opposing directions, controlled only by the level of its expression. This biphasic response was shown in two different cell lines, and confirmed and extended our initial observations with the stably transfected, constitutively expressing cells. It is also consistent with our initial findings with the CaSki and SiHa cells, where the CaSki cells, with approximately 600 copies of the HPV genome, were sensitive to TNF, while the SiHa cells, with only 1-2 copies of the genome, were resistant. Finally, our finding of both sensitizing and protective effects from E6 may explain the discrepant responses noted in the literature.

The relationship between the effect of E6 on the cellular responses to TNF and to anti-Fas is complex, with low levels of E6 providing protection from TNF and high levels providing protection from Fas. Currently, little is known about the relative amounts of E6 produced by HPV 16 during the different stages of the viral life cycle. Papillomaviruses initially infect the basal cells, where they replicate within the host cell as an episome. As the cells become more differentiated and move up through the layers, the virus enters a vegetative state that involves the production of progeny virions (reviewed by Longworth and Laimins ${ }^{66}$ ). It may be that apoptosis is more likely to be triggered by TNF or by Fas depending on where the virus is in its life cycle, suggesting that the virus may optimize its protection at each stage by manipulating the amount of E6 produced. Further research will be required to understand the role of E6 in the virus life cycle. It is of interest to note that in the case of Fas, and in contrast to the case with $\mathrm{TNF}$, the dose dependence of the response was simple and monotonic, with increased levels of E6 leading to increased protection. $^{17}$

The mechanism for protection may be reasonably well explained by the facts that E6 binds to the C-terminus of TNF $\mathrm{R} 1$ and prevents signal transduction through TRADD, ${ }^{16}$ and that it also binds to FADD and promotes its degradation. ${ }^{17}$ The mechanism underlying sensitization is not yet known and is the subject of ongoing study. It may be that under some conditions, E6 is able to interact with components of the cell death pathway in such a way as to form an 'artificial DISC,' thus priming the cell for engagement of the apoptotic pathway once TNF binds to its receptor.

The question of what these results may mean in the context of a natural infection is an intriguing one. The literature contains a number of reports regarding the response of epithelial cells harboring HPV sequences to TNF, and these reports provide mixed conclusions. For example, several studies examined the influence of TNF on the growth of keratinocytes that did or did not express some or all of the HPV 16 or 18 genes. When all or most of the HPV genome was present, several groups found that TNF treatment inhibited growth of keratinocytes containing HPV, ${ }^{67-69}$ although this may not be the case for cells with HPV $18 .{ }^{69}$ In contrast, when the influence of HPV 16 E7 was examined in isolation, it overcame the ability of TNF to mediate growth arrest. $^{70}$ When apoptosis rather than growth arrest was 
examined, mixed results were again observed. In one paper in which the entire HPV 18 sequence was present, the authors found that it conferred resistance to TNF. ${ }^{71} \mathrm{E} 7$, on the other hand, has been reported both to protect ${ }^{72}$ and to sensitize ${ }^{73}$ human fibroblasts or keratinocytes, respectively, from TNF. Our own results with the CaSki and SiHa cells (Figure 1) are consistent with the E6 dose-dependent response we have worked out in greater molecular detail in the U2OS cells, and it may be that dosage effects are important for viral proteins other than E6. Undoubtedly, the situation in a natural infection will be quite complex with several different viral proteins each having their own independent and cooperative impacts on a cellular response.

This complexity is also likely to relate to the necessity that we and others have found for the use of agents such as cycloheximide to induce or uncover TNF sensitivity. TNF is known to simultaneously activate pathways leading to apoptosis and to survival (largely mediated by NF- $\kappa \mathrm{B}),{ }^{74}$ with the balance of activities very dependent on the cellular context. In general, most normal cells are resistant to TNF, while many virus-infected and some tumor cells are sensitive to the cytokine, and the molecular basis for this difference is likely due in large part to the availability of inhibitor of apoptosis proteins (IAPs). ${ }^{75,76}$ Viruses can modulate this balance. In the adenovirus system, for example, it has been shown that the existence of several virus-encoded proteins that block TNF-induced apoptosis ${ }^{77-79}$ may be necessitated by the actions of the adenovirus E1A protein, which sensitizes cells to TNF, likely as a 'side effect' of its other biological activities. ${ }^{58,80,81}$ In the experiments reported here, we were unable to observe significant cell death in response to TNF in the absence of cycloheximide in any of the cells tested (control cells, cells expressing high levels of E6 and cells expressing low levels of E6) (data not shown). It seems likely, although not yet demonstrated, that in a manner analogous to the adenovirus system, some event or protein involved in HPV infection sensitizes the cells to TNF, resulting in the necessity for one or more virus-encoded proteins (such as E6) to abrogate this sensitivity. The biological relevance for the sensitizing function of E6 is not clear, and is the subject of continuing investigation in our lab.

Virus-host interactions can be quite complex, as these results illustrate. Furthermore, an understanding of the quantitative, and not simply the qualitative aspects of gene and protein expression, may be required in order to develop the models that are necessary both for scientific understanding and for the development of novel and effective therapeutic responses.

\section{Materials and Methods}

\section{Reagents}

Lyophilized human recombinant TNF- $\alpha$ (R\&D Systems, Minneapolis, MN, USA) was dissolved in phosphate-buffered saline (PBS) to yield a $1 \mu \mathrm{g} / \mathrm{m}$ stock, with aliquots stored at $-80^{\circ} \mathrm{C}$. MTT (Sigma, St. Louis, MO, USA) was dissolved in PBS, and mitomycin C (Roche Molecular Biochemicals, Indianapolis, IN, USA) was dissolved in dimethyl sulfoxide (DMSO) to stock concentrations of $5 \mathrm{mg} / \mathrm{ml}$ and stored at $4^{\circ} \mathrm{C}$ until use. Cycloheximide (Sigma, St. Louis, MO, USA) was prepared as a $5 \mathrm{mg} / \mathrm{ml}$ stock in PBS, C2- ceramide (Biomol, Plymouth Meeting, PA, USA) was dissolved in DMSO to yield a $25 \mathrm{mM}$ stock and doxycycline (Clontech, Palo Alto, CA, USA) was dissolved in PBS to yield a $1 \mathrm{mg} / \mathrm{ml}$ stock. These three solutions were stored at $-20^{\circ} \mathrm{C}$. STS was obtained from Alexis Biochemicals (San Diego, CA, USA) and tert-butyl hydroxoperoxide was obtained from Acros Organics (New Jersey). Z-VAD-FMK and cyclosporine A were both obtained from Biomol (Plymouth Meeting, PA, USA) and dissolved in DMSO to stock concentrations of 10 and $100 \mathrm{mM}$, respectively.

Monoclonal antibodies directed against Fas (clone $\mathrm{CH}-11$ ) (Medical and Biological Laboratories Co., LTD, Nagoya, Japan) were dissolved in PBS to yield a $500 \mu \mathrm{g} / \mathrm{ml}$ stock. The monoclonal antibodies anti-HA (Roche, Indianapolis, IN, USA), anti- $\beta$-actin, anti-lamin B, anti-TRADD and anti-TNFRI (Santa Cruz Biotechnology), anti-PARP (Calbiochem), anti-p53 (DO-7) (Novacastra Labs, UK) and anti-Topo I (highly specific autoimmune serum obtained as a generous gift from Dr. Eng Tan, Scripps Research Institute) were aliquoted and stored at $-20^{\circ} \mathrm{C}$ prior to usage, as were the mouse monoclonal and rat polyclonal peroxidase-coupled anti-HA antibodies (Roche Molecular Biochemicals, Indianapolis, IN, USA).

\section{Cell culture}

U2OS cells, derived from a human osteosarcoma, were obtained from the ATCC (Manassas, VA, USA) and were cultured in McCoy's 5A medium (Invitrogen, Carlsbad, CA, USA) supplemented with $10 \%$ fetal bovine serum (Invitrogen), penicillin $(100 \mathrm{U} / \mathrm{ml})$ and streptomycin $(100 \mu \mathrm{g} / \mathrm{ml})$ (Sigma). SiHa cells, derived from a squamous cell carcinoma, were also obtained from the ATCC and were cultured in Eagle's minimal essential medium (Invitrogen) supplemented with $10 \%$ fetal bovine serum (Invitrogen), penicillin $(100 \mathrm{U} / \mathrm{ml})$ and streptomycin $(100 \mu \mathrm{g} / \mathrm{ml})$ (Sigma). CaSki cells, derived from an epidermoid carcinoma, were also derived from the ATCC and were cultured in RPMI 1640 medium (Invitrogen) supplemented with $10 \%$ fetal growth serum, penicillin $(100 \mathrm{U} / \mathrm{ml})$ and streptomycin $(100 \mu \mathrm{g} / \mathrm{ml})$ (Sigma).

\section{Plasmids}

A plasmid expressing epitope-tagged HPV 16 E6 was generated by first inserting the CMV promoter (from pC1neo, Promega, Madison, WI, USA) into the Bgll-EcoRI site of the promoterless plasmid pEGFP-1 (Clontech, Palo Alto, CA, USA). The PCR product of E6 (derived from plasmid pSG16E $6^{16}$ ) was then cloned into HA-tag Bluescript KS in both the sense and antisense orientations, and the sense and antisense versions of HA-E6 were then cloned into the pEGFP-1 plasmid by exchange with EGFP at the Xhol-Notl site. The resulting plasmids then had the HA epitope tag appended to the N-terminus of E6 in either the sense (pHA-E6 S) or the antisense (pHA-E6 AS) orientation.

The gene encoding the death domain of human TNF R1 (obtained from Carl Ware, La Jolla Institute for Allergy and Immunology, San Diego, CA, USA) was cloned into the Hindlll site of the pVP16 plasmid from the Mammalian Two-Hybrid System (Clontech, Palo Alto, CA, USA) in-frame with the activation domain. Removal of the Sacll-Xbal fragment, coding for the C-terminal 41 amino acids and including the putative E6 binding site, created a plasmid coding for a truncated version of the TNF R1 death domain (amino acids 185-415; pVP TNF R1 $\Delta$ DD).

The pTet-Off plasmids coding for tTA (tetracycline activator), pTRE-luc, coding for luciferase under the control of the tTA, pTK-Hyg, coding for hygromycin resistance, as well as the cloning plasmid pTRE2 were obtained from and described in the Tet-Off kit from Clontech. pTRE-HA-E6 was obtained by cloning the HindIII blunt end-BamHI fragment from $\mathrm{pHA}$ E6 S into the EcoRI blunt end-BamHI sites of the pTRE2 vector. 


\section{Transfections}

Transfections were carried out using Fugene VI (Roche Molecular Biochemicals, Indianapolis, IN, USA) as directed by the manufacturer. For transient transfections, cells were analyzed $48 \mathrm{~h}$ post-transfection. For stable transfections, clones were passaged into selection media containing G418 (500 $\mu \mathrm{g} / \mathrm{ml})$. Individual clones were selected, grown and analyzed for protein expression by immunoprecipitation and immunoblotting.

\section{Treatment of cells with TNF, mitomycin C, cyclosporine A, ceramide, MNNG, staurosporine, tert-butyl hydroperoxide and Z-VAD-FMK}

To measure cell survival following TNF treatment, cells were seeded into 96-well plates $\left(1 \times 10^{4}\right.$ cells/well) and allowed to adhere overnight. TNF (final concentration of 1,5 or $20 \mathrm{ng} / \mathrm{ml}$ ) was then added in the presence of cycloheximide (final concentration of $5 \mu \mathrm{g} / \mathrm{ml}$ ) and the cells were incubated for $16 \mathrm{~h}$ prior to measuring the number of viable cells by the MTT assay (described below).

To determine the ability of cells to accumulate increased levels of p53 following DNA damage, cells were treated with mitomycin $\mathrm{C}$ and assayed for the resulting p53 levels. Cells were seeded into 24-well plates $\left(1 \times 10^{5}\right.$ cells/well) or into six-well plates $\left(1 \times 10^{6}\right.$ cells/well $)$ and allowed to adhere overnight. Approximately $24 \mathrm{~h}$ later, mitomycin $\mathrm{C}$ was added to $\mathrm{a}$ final concentration of $2 \mu \mathrm{g} / \mathrm{ml}$ medium. After $0,3,6$ or $16 \mathrm{~h}$, cells were harvested, and the lysates analyzed for $p 53$ by Western blot or ELISA (described below).

To see if cyclosporine A treatment would protect cells from TNF, the indicated clones were treated with cyclosporine $A(50 \mu \mathrm{M})$ simultaneously with exposure to TNF and cycloheximide, and cell survival was measured $16 \mathrm{~h}$ later. To determine cell survival following ceramide treatment, cells were seeded into 96 -well plates $\left(2 \times 10^{4}\right.$ cells/well) and allowed to adhere overnight. The media were then removed and replaced with media supplemented to contain $2 \%$ serum. Ceramide was then added to the indicated final concentration, and cells were incubated for $16 \mathrm{~h}$ prior to measurement of the number of viable cells by the MTT assay. For the MNNG experiments, cells were treated with the indicated concentrations of MNNG for $16 \mathrm{~h}$, and cell viability measured using the MTT assay.

To determine the cleavage patterns seen during apoptosis and necrosis, U2OS cells were either untreated or treated with STS $(4 \mu \mathrm{M})$ or with $\mathrm{TBH}(250 \mu \mathrm{M})$ for $6 \mathrm{~h}$ prior to lysis and analysis by immunoblot.

To determine whether cell death following TNF treatment was caspase dependent, the indicated cells were treated with cycloheximide and TNF in the presence or absence of Z-VAD-FMK $(50 \mu \mathrm{M})$.

\section{Cell viability assays}

MTT

The incubation media were first removed and exchanged with $80 \mu \mathrm{l}$ of fresh media. A $20 \mu \mathrm{l}$ portion of MTT was then added ( $5 \mathrm{mg} / \mathrm{ml}$ stock) and cells were incubated at $37^{\circ} \mathrm{C}$ for $3 \mathrm{~h}$. The media were removed, and then $150 \mu \mathrm{l}$ of DMSO was added and allowed to incubate for $10 \mathrm{~min}$. The solution was mixed by pipetting, and the absorbance of each well at $490 \mathrm{~nm}$ was measured.

\section{Crystal violet}

The incubation media were first removed and exchanged with $100 \mu \mathrm{l}$ of $4 \%$ paraformaldehyde in PBS. After 20 min, the fixative was removed, cells were washed twice with PBS and $100 \mu \mathrm{l}$ of a $0.55 \%$ solution of crystal violet solution (Sigma) was added. After an incubation period of $30 \mathrm{~min}$, the cells were washed with PBS to remove any unbound stain. The bound crystal violet was then dissolved in $100 \mu \mathrm{l}$ of a $10 \%$ acetic acid solution. The solution was mixed by pipetting and the absorbance of each well at $570 \mathrm{~nm}$ was measured.

\section{Immunoblotting}

Cells $\left(2 \times 10^{6}\right)$ were lysed in $100 \mu$ l of lysis buffer ( $50 \mathrm{mM}$ Tris-Hcl, $\mathrm{pH} 7.5$, $150 \mathrm{mM} \mathrm{NaCl}, 1 \%$ Triton X-100, $1 \mathrm{mM}$ EDTA, $1 \mathrm{mM}$ PMSF). One tablet of protease inhibitor cocktail (Roche) per $10 \mathrm{ml}$ buffer was added just prior to use. The protein concentration in cleared lysates was measured using the Bio-Rad Protein Assay (Bio-Rad), and $1 \mathrm{mM}$ DTT was added after the measurement of protein content.

Lysates (10-50 $\mu \mathrm{g}$ protein/lane) were subjected to $12 \%$ SDS-PAGE and transferred to Immobilon $\mathrm{P}$ membranes (Millipore Corp.). After treating the membranes with $5 \%$ nonfat milk, primary antibodies diluted in TBST plus $1 \%$ BSA were applied in TBST (50 mM Tris- $\mathrm{HCl}$, pH 7.5, $150 \mathrm{mM}$ $\mathrm{NaCl}, 0.1 \%$ Tween 20). After incubation with rocking (room temperature, $1 \mathrm{~h})$, membranes were washed with TBST. Secondary ImmunoPure Antibodies (anti-mouse) conjugated with horseradish peroxidase (Pierce) were applied to the membrane for $1 \mathrm{~h}$, and signals detected using the chemiluminescent SuperSignal West Femto or Pico Maximum Sensitivity substrate (Pierce). A horseradish peroxidase-conjugated goat anti-human antibody (Zymed, South San Francisco, CA, USA) was used to detect binding of human anti-Topo I antibodies.

\section{Immunoprecipitation}

Cells $\left(2-5 \times 10^{6}\right)$ were lysed in $500 \mu$ l of lysis buffer and the cleared lysates incubated with $2 \mu \mathrm{g}$ of monoclonal anti-HA antibody (Roche) at $4^{\circ} \mathrm{C}$ for $1 \mathrm{~h}$ with rotation. Protein plus A/G-agarose slurry $(50 \mu \mathrm{l})$ (Santa Cruz Biotechnology) was added to each lysate, and lysates were incubated for $2 \mathrm{~h}$ at $4{ }^{\circ} \mathrm{C}$. The protein $A / G$ slurry was then washed three times with lysis buffer, followed by one wash with high-salt buffer $(50 \mathrm{mM}$ Tris- $\mathrm{HCl}, \mathrm{pH} 7.5,500 \mathrm{mM} \mathrm{NaCl}, 0.1 \%$ NP-40, $1 \mathrm{mM}$ EDTA, $1 \mathrm{mM}$ DTT) and one wash with buffer lacking $\mathrm{NaCl}$. The precipitates were fractionated by $12 \%$ SDS-PAGE and immunoblotting was performed as described above.

\section{RT-PCR}

RT-PCR was used to analyze the U2OS and U2OSE617 cell lines for the presence of message coding for E6. A $3.5 \mu \mathrm{g}$ portion of total RNA was isolated from each cell line and used as a template. cDNA was synthesized using SuperScript II reverse transcriptase (Invitrogen) and an oligo(dT) primer (Amersham). Primers for the $5^{\prime}$ and $3^{\prime}$ ends of $E 6\left(5^{\prime}\right.$ GCACCAAAAGAGAACTGCAATGT- $3^{\prime}$ and $5^{\prime}$-TGGGTTTCTCTACG TGTTCTTGAT- $3^{\prime}$ ) were used to amplify PCR products for the E6 full length and splice variant from $c D N A$ using $1 / 20$ of the total $c D N A$ reaction mixture. To control for possible contamination by genomic DNA, parallel reactions were run using $0.175 \mu \mathrm{g}$ of total RNA in the absence of the reverse transcriptase enzyme.

\section{p53 ELISA}

Cells were assayed for p53 by ELISA as described previously. ${ }^{16}$ Cells were lysed in lysis buffer $\left(50 \mathrm{mM} \mathrm{Na} \mathrm{HPO}_{4}, 17 \mathrm{mM} \mathrm{NaH} \mathrm{PO}_{4}, 68 \mathrm{mM}\right.$ $\mathrm{NaCl}, 1 \%$ Triton $\mathrm{X}-100,0.5 \%$ sodium deoxycholate, $0.1 \%$ SDS, $\mathrm{pH} 7.4$, with $1 \%$ aprotinin added before use), and lysates were stored at $-80^{\circ} \mathrm{C}$ 
for no more than 1 week prior to analysis. Monoclonal antibody pAB 122 (hybridoma obtained from ATCC, and antibodies were purified from the culture medium using protein-A Sepharose) was used as the primary or capture antibody, biotinylated anti-p53 (Roche) was used as the detection antibody and glutathione S-transferase (GST)-p53 (Santa Cruz Biotechnology) was used as a standard. Each sample was measured in triplicate, and the results were normalized to the amount of protein present in each sample. Protein concentration was determined using the Bio-Rad Protein Assay (Bio-Rad).

\section{Morphological analysis of apoptotic cells}

Cells were seeded on coverslips in a six-well plate and allowed to incubate overnight. The following day, they were treated with TNF plus cycloheximide. After the indicated time, slides were fixed in a solution of $4 \%$ paraformaldehyde in PBS and then mounted using Vestashield mounting medium with 4',6-diamidino-2-phenylindole (DAPI) (Vector Laboratories Inc., Burlingame, CA, USA). The morphology of these cells was then analyzed by phase-contrast microscopy (Olympus BX50, Japan). The DAPI-stained nuclei were monitored using the UplanFI objective. The percentage of apoptotic cells was expressed as the percentage of cells exhibiting condensed nuclei and/or nuclei with fragmentations or cytoplasmic blebbing as compared to the total number of nuclei examined. At least 200 nuclei were counted for each determination.

\section{Caspase 3 and 8 assays}

Cells were plated into black 96 -well plates at a density of $1 \times 10^{4}$ cells/well and incubated overnight. TNF $(5 \mathrm{ng} / \mathrm{ml})$ was then added, along with cycloheximide $(5 \mu \mathrm{g} / \mathrm{ml})$ for the times indicated. Caspase activity was then measured using the fluorogenic substrate DEVD-AMC for caspase 3 and IETD-AMC for caspase 8 (Alexis Biochemicals) as described. ${ }^{82}$ Briefly, cells (in a total volume of $40 \mu \mathrm{l}$ media/well) were lysed by the addition of $20 \mu \mathrm{l}$ of $3 \times$ lysis buffer ( $150 \mathrm{mM} \mathrm{HEPES}, \mathrm{pH} 7.4,450 \mathrm{mM} \mathrm{NaCl}, 150 \mathrm{mM}$ $\mathrm{KCl}, 1.2 \mathrm{mM}$ EGTA, 1.5\% Nonidet P-40, 0.3\% CHAPS, 30\% sucrose, $30 \mathrm{mM}$ DTT, 3 mM PMSF), which included either substrate alone (150 $\mu \mathrm{M})$ or substrate plus inhibitor $(2 \mu \mathrm{g} / \mathrm{ml})$. The inhibitor for caspase 3 was DEVD-CHO and the inhibitor for caspase 8 was IETD-CHO (BD Pharmingen). After 2, 6 and $16 \mathrm{~h}$ of incubation, the released fluorochrome was measured with a plate-reading fluorimeter (Flx800, Bio-Tek Instrument Co) using an excitation of $360 \mathrm{~nm}$ and an emission of $460 \mathrm{~nm}$. The activity in wells treated with the inhibitor was subtracted from the activity in wells lacking the inhibitor. For the caspase 3 measurements, the resulting difference was expressed as a percentage of caspase 3 activity in the untreated parental cells. In the case of the caspase 8 measurements, the untreated cells had essentially undetectable activity, so activities were normalized to the low but measurable values obtained at $1.5 \mathrm{~h}$. Each measurement was performed in triplicate, and error bars represent the standard deviation.

\section{Development and use of the Tet-Off system}

U2OS cells capable of expressing variable amounts of HA-E6, regulated by the amount of dox present in the media, were created using the Tet-Off system (Clontech) by following the manufacturer's protocol with some modifications. ${ }^{17}$ Cultures of these cells were grown in the indicated concentrations of dox for 2 days prior to use, and the indicated concentrations of dox were maintained in the media throughout each experiment.

\section{Acknowledgements}

This work was supported in part by NCl Grant 1 R01 CA-095461 (PDH) and NIAID Grant R29 Al-44088 (CAC) from the National Institutes of Health. In addition, we thank Dr. Eng Tan (Scripps Research Institute) for the Topo I antibody, Dr. Carl Ware (La Jolla Institute for Allergy and Immunology) for the plasmid encoding TNF R1 and Christine Molinaro (Loma Linda University) for her technical assistance.

\section{References}

1. Howley PM, Munger K, Romanczuk H, Scheffner M and Huibregtse JM (1992) Cellular Targets of the Oncoproteins Encoded by the Cancer Associated Human Papillomaviruses (Boca Raton, FL: CRC Press; Japan Sci. Soc. Press: Tokyo) pp. 239-248

2. Scheffner M, Werness BA, Huibregtse JM, Levine AJ and Howley PM (1990) The E6 oncoprotein encoded by human papillomavirus types 16 and 18 promotes the degradation of p53. Cell 63: 1129-1136

3. Patel D, Huang SM, Baglia LA and McCance DJ (1999) The E6 protein of human papillomavirus type 16 binds to and inhibits co-activation by CBP and p300. EMBO J. 18: 5061-5072

4. Zimmermann H, Degenkolbe R, Bernard H and O'Connor M (1999) The human papillomavirus type 16 E6 oncoprotein can down-regulate p53 activity by targeting the transcriptional coactivator CBP/p300. J. Virol. 73: 6209-6219

5. Ronco LV, Karpova AY, Vidal M and Howley PM (1998) Human papillomavirus 16 E6 oncoprotein binds to interferon regulatory factor-3 and inhibits its transcriptional activity. Genes Dev. 12: 2061-2072

6. Kukimoto I, Aihara S, Yoshiike K and Kanda T (1998) Human papillomavirus oncoprotein $\mathrm{E} 6$ binds to the $\mathrm{C}$-terminal region of human minichromosome maintenance 7 protein. Biochem. Biophys. Res. Commun. 249: 258-262

7. Kuhne $C$ and Banks L (1998) E3-ubiquitin ligase/E6-AP links multicopy maintenance protein 7 to the ubiquitination pathway by a novel motif, the L2G box. J. Biol. Chem. 273: 34302-34309

8. Gao Q, Srinivasan S, Boyer SN, Wazer DE and Band V (1999) The E6 oncoproteins of high-risk papillomaviruses bind to a novel putative GAP protein, E6TP1, and target it for degradation. Mol. Cell. Biol. 19: 733-744

9. Zeng M, Kumar A, Meng G, Gao Q, Dimri G, Wazer DE, Band H and Band V (2002) Human papillomavirus 16 E6 oncoprotein inhibits retinoic $X$ receptormediated transactivation by targeting human ADA3 coactivator. J. Biol. Chem. 277: 45611-45618

10. Kumar A, Zhao Y, Meng G, Zeng M, Srinivasan S, Delmolino LM, Gao Q, Dimri G, Weber GF, Wazer DE, Band H and Band V (2002) Human papillomavirus oncoprotein E6 inactivates the transcriptional coactivator human ADA3. Mol. Cell. Biol. 22: $5801-5812$

11. Gupta S, Takhar PP, Degenkolbe R, Koh CH, Zimmermann H, Yang CM, Guan Sim K, Hsu SI and Bernard HU (2003) The human papillomavirus type 11 and 16 E6 proteins modulate the cell-cycle regulator and transcription cofactor TRIP-Br1. Virology 317: 155-164

12. Lu Z, Hu X, Li Y, Zheng L, Zhou Y, Jiang H, Ning T, Basang Z, Zhang $C$ and Ke Y (2004) Human papillomavirus 16 E6 oncoprotein interferences with insulin signaling pathway by binding to tuberin. J. Biol. Chem. 279: 35664-35670

13. Thomas $M$ and Banks $L$ (1998) Inhibition of Bak-induced apoptosis by HPV-18 E6. Oncogene 17: 2943-2954

14. Veldman T, Liu X, Yuan H and Schlegal R (2003) Human papillomavirus E6 and Myc proteins associate in vivo and bind to and cooperatively activate the telomerase reverse transcriptase promoter. Proc. Natl. Acad. Sci. USA 100: 8211-8216

15. Tross-Mesilaty S, Reinstein E, Bercovich B, Tobias KE, Schwartz AL, Kahana C and Ciechanover A (1998) Basal and human papillomavirus E6 oncoproteininduced degradation of Myc proteins by the ubiquitin pathway. Proc. Natl. Acad. Sci. USA 95: 8058-8063

16. Filippova M, Song H, Connolly JL, Dermody TS and Duerksen-Hughes PJ (2002) The human papillomavirus 16 E6 protein binds to Tumor Necrosis Factor (TNF) R1 and protects cells from TNF-induced apoptosis. J. Biol. Chem. 277: 21730-21739 
17. Filippova M, Parkhurst $L$ and Duerksen-Hughes PJ (2004) The human papillomavirus 16 E6 protein binds to Fas-Associated Death Domain and protects cells from Fas-triggered apoptosis. J. Biol. Chem. 279: 25729-25744

18. Tong X and Howley PM (1997) The bovine papillomavirus E6 oncoprotein interacts with paxillin and disrupts the actin cytoskeleton. Proc. Natl. Acad. Sci. USA 94: 4412-4417

19. Chen JJ, Reid CE, Band V and Androphy EJ (1995) Interaction of papillomavirus E6 oncoproteins with a putative calcium-binding protein. Science 269: 529-531

20. Degenhardt $Y Y$ and Silverstein $S$ (2001) Interaction of zyxin, a focal adhesion protein, with the E6 protein from human papillomavirus type 6 results in its nuclear translocation. J. Virol. 23: 11791-11802

21. Du M, Fan X, Hong E and Chen JJ (2002) Interaction of oncogenic papillomavirus E6 proteins with fibulin-1. Biochem. Biophys. Res. Commun. 296: 962-969

22. Kiyono T, Hiraiwa A, Fujita M, Hayashi Y, Akiyama T and Ishibashi M (1997) Binding of high-risk human papillomavirus $E 6$ oncoproteins to the human homologue of the Drosophila discs large tumor suppressor protein. Proc. Natl. Acad. Sci. USA 94: 11612-11616

23. Lee SS, Weiss RS and Javier RT (1997) Binding of human virus oncoproteins to $\mathrm{hDlg} / \mathrm{SAP} 97$, a mammalian homolog of the Drosophila disks large tumor suppressor protein. Proc. Natl. Acad. Sci. USA 94: 6670-6675

24. Nakagawa S and Huibregtse JM (2000) Human scribble (Vartul) is targeted for ubiquitin-mediated degradation by the high-risk papillomavirus $\mathrm{E} 6$ proteins and the E6AP ubiquitin-protein ligase. Mol. Cell. Biol. 20: 8244-8253

25. Thomas M, Glausinger BA, Pim D, Javier RT and Banks L (2001) HPV E6 and MAGUK protein interactions: determination of the molecular basis for specific protein recognition and degradation. Oncogene 20: 5431-5439

26. Glausinger BA, Lee SS, Thomas M, Banks L and Javier RT (2000) Interactions of the PDZ-protein MAGI-1 with adenovirus E4-ORF1 and high-risk papillomavirus E6 oncoproteins. Oncogene 19: 5270-5280

27. Thomas M, Laura R, Hepner K, Guccione E, Sawyers C, Lasky L and Banks L (2002) Oncogenic human papillomavirus E6 proteins target the MAGI-2 and MAGI-3 proteins for degradation. Oncogene 21: 5088-5096

28. Lee SS, Glausinger BA, Mantovani F, Banks L and Javier RT (2000) Multi-PDZ domain protein MUPP1 is a cellular target for both adenovirus E4-ORF1 and high-risk papillomavirus type 18 E6 oncoproteins. J. Virol. 74: 9680-9693

29. Iftner T, Ebel M, Schopp B, Hiler T, Loizou Jl, Caldecott KW and Stubrenrauch F (2002) Interference of papillomavirus E6 protein with single-strand break repair by interaction with XRCC1. EMBO J. 21: 47141-47148

30. Srivenugopal KS and Ali-Osman F (2002) The DNA repair protein, $O(6)$ methylguanine-DNA methyltransferase is a proteolytic target for the E6 human papillomavirus oncoprotein. Oncogene 21: 5940-5945

31. Benedict CA, Banks TA and Ware CF (2003) Death and survival: viral regulation of TNF signaling pathways. Curr. Opin. Immunol. 15: 59-65

32. Benedict CA (2003) Viruses and the TNF-related cytokines, an evolving battle. Cytokine Growth Factors Rev. 14: 349-357

33. Finzer P, Aguilar-Lemarroy A and Rosl $F$ (2002) The role of human papillomavirus oncoproteins E6 and E7 in apoptosis. Cancer Lett. 188: 15-24

34. Vikhanskaya F, Falugi C, Valente $P$ and Russo $P$ (2002) Human papillomavirus type 16 E6-enhanced susceptibility to apoptosis induced by TNF in A2780 human ovarian cancer cell line. Int. J. Cancer 97: 732-739

35. Liu Y, Tergaonkar V, Krishna S and Androphy EJ (1999) Human papillomavirus type 16 E6-enhanced susceptibility of L929 cells to tumor necrosis factor alpha correlates with increased accumulation of reactive oxygen species. J. Biol. Chem. 274: 24819-24827

36. Duerksen-Hughes PJ, Yang J and Schwartz SB (1999) HPV 16 E6 blocks TNFmediated apoptosis in mouse fibroblast LM cells. Virology 264: 55-65

37. ATCC (2005) CRL-1550, HTB-35; http://www.atcc.org.

38. Yang $\mathrm{J}$ and Duerksen-Hughes PJ (1998) A new approach to identifying genotoxic carcinogens: p53 induction as an indicator of genotoxic damage. Carcinogenesis 19: 1117-1125

39. Luschen S, Ussat S, Scherer G, Kabelitz D and Adam-Klages S (2000) Sensitization to death receptor cytotoxicity by inhibition of fas-associated death domain protein (FADD)/caspase signaling. Requirement of cell cycle progression. J. Biol. Chem. 275: 24670-24678

40. Vercammen D, Beyaert R, Denecker G, Goossens V, Van Loo G, Declercq W, Grooten J, Fiers W and Vandenabeele P (1998) Inhibition of caspases increases the sensitivity of L929 cells to necrosis mediated by tumor necrosis factor. J. Exp. Med. 187: 1477-1485

41. Casiano CA, Martin SJ, Green DR and Tan EM (1996) Selective cleavage of nuclear autoantigens during CD95 (Fas/APO-1)-mediated T cell apoptosis. J. Exp. Med. 184: 765-770

42. Casiano CA, Ochs RL and Tan EM (1998) Distinct cleavage products of nuclear proteins in apoptosis and necrosis revealed by autoantibody probes. Cell Death Differ. 5: 183-190

43. Wu X, Molinaro C, Johnson N and Casiano CA (2001) Secondary necrosis is a source of proteolytically modified forms of specific intracellular autoantigens: implications for systemic autoimmunity. Arthritis Rheum. 44: 2642-2652

44. Scaffidi C, Schmitz I, Zha J, Korsmeyer SJ, Krammer PH and Peter ME (1999) Differential modulation of apoptosis sensitivity in CD95 type I and type II cells. J. Biol. Chem. 274: 22532-22538

45. Scaffidi C, Fulda S, Srinivasan A, Friesen C, Li F, Tomaselli KJ, Debatin KM, Krammer PH and Peter ME (1998) Two CD95 (APO-1/Fas) signaling pathways. EMBO J. 17: 1675-1687

46. Seaton TA, Cooper JM and Schapira AH (1998) Cyclosporin inhibition of apoptosis induced by mitochondrial complex I toxins. Brain Res. 809: 12-17

47. Zamzami N, Marchetti P, Castedo M, Hirsch T, Susin SA, Masse B and Kroemer G (1996) Inhibitors of permeability transition interfere with the disruption of the mitochondrial transmembrane potential during apoptosis. FEBS Lett. 384: 53-57

48. Friberg H, Ferrand-Drake M, Bengtsson F, Halestrap AP and Wieloch T (1998) Cyclosporin A, but not FK 506, protects mitochondria and neurons against hypoglycemic damage and implicates the mitochondrial permeability transition in cell death. J. Neurosci. 18: 5151-5159

49. Walter DH, Haendeler J, Galle J, Zeiher AM and Dimmeler S (1998) Cyclosporin A inhibits apoptosis of human endothelial cells by preventing release of cytochrome $C$ from mitochondria. Circulation 98: 1153-1157

50. Baines CP, Kaiser RA, Purcell NH, Blair NS, Osinska H, Hambleton MA, Brunskill EW, Sayen MR, Gottlieb RA, Dorn GWI, Robbins J and Molkentin JD (2005) Loss of cyclophilin D reveals a critical role for mitochondrial permeability transition in cell death. Nature 434: 658-662

51. Nakagawa T, Shimizu S, Watanabe T, Yamaguchi O, Otsu K, Yamagata $\mathrm{H}$, Inohara $\mathrm{H}$, Kubo $\mathrm{T}$ and Tsujimoto $\mathrm{Y}$ (2005) Cyclophilin D-dependent mitochondrial permeability transition regulates some necrotic but not apoptotic cell death. Nature 434: 652-658

52. Yang $\mathrm{J}$ and Duerksen-Hughes PJ (2001) Activation of a p53-independent, sphingolipid-mediated cytotolytic pathway in p53-negative mouse fibroblast cells treated with $N$-methyl- $N$-nitro- $N$-nitrosoguanidine. J. Biol. Chem. 276: 27129-27135

53. Obeid LM, Linardic CM, Karolak LA and Hannun YA (1993) Programmed cell death induced by ceramide. Science 259: 1769-1771

54. Benedict CA and Ware CF (2001) Virus targeting of the tumor necrosis superfamily. Virology 289: 1-5

55. Hay $S$ and Kannourakis $G$ (2002) A time to kill: viral manipulation of the cell death program. J. Gen. Virol. 83: 1547-1564

56. Tortorella D, Gewurz BE, Furman MH, Schust DJ and Ploegh HL (2000) Viral subversion of the immune system. Annu. Rev. Immunol. 18: 861-926

57. Benedict CA, Norris PS and Ware CF (2002) To kill or be killed: viral evasion of apoptosis. Nat. Immunol. 3: 1013-1018

58. Shisler J, Duerksen-Hughes PJ, Hermiston TM, Wold WS and Gooding LR (1996) Induction of susceptibility to tumor necrosis factor by E1A is dependent on binding to either $\mathrm{p} 300$ or p105-Rb and induction of DNA synthesis. J. Virol. 70: 68-77

59. Morrison TE, Mauser A, Klingelhutz A and Kenney SC (2004) Epstein-Barr virus immediate-early protein BZLF1 inhibits tumor necrosis factor alphainduced signaling and apoptosis by downregulating tumor necrosis factor receptor 1. J. Virol. 78: 544-549

60. Kieser A, Kaiser C and Hammerschmidt W (1999) LMP1 signal transduction differs substantially from TNF receptor 1 signaling in the molecular functions of TRADD and TRAF2. EMBO J. 18: 2511-2521

61. Baillie J, Sahlender DA and Sinclair JH (2003) Human cytomegalovirus infection inhibits tumor necrosis factor alpha (TNF- $\alpha$ ) signaling by targeting the 55-kilodalton TNF- $\alpha$ receptor. J. Virol. 77: 7007-7016

62. Bertin J, Armstrong RC, Ottilie S, Martin DA, Wang Y, Banks S, Wang G-H, Senkevich TG, Alnemri ES, Moss B, Lenardo MJ, Tomaselli KJ and Cohen JI (1997) Death effector domain-containing herpesvirus and poxvirus proteins 
inhibit both Fas- and TNFR1-induced apoptosis. Proc. Natl. Acad. Sci. USA 94: $1172-1176$

63. Garvey TL, Bertin J, Siegel RM, Wang G-H, Lenardo MJ and Cohen JI (2002) Binding of FADD and caspase-8 to Molluscum Contagiosum virus MC159 v-FLIP is not sufficient for its antiapoptotic function. J. Virol. 76: 697-706

64. Hu S, Vincenz C, Buller M and Dixit VM (1997) A novel family of viral death effector domain-containing molecules that inhibit both CD95 and tumor necrosis factor receptor 1-induced apoptosis. J. Biol. Chem. 272: 9621-9624

65. Stenner-Liewen F, Liewen H, Zapata JM, Pawlowski K, Godzik A and Reed JC (2002) CADD, a Chlamydia protein that interacts with death receptors. J. Biol. Chem. 277: 9633-9636

66. Longworth MS and Laimins LA (2004) Pathogenesis of human papillomaviruses in differentiating epithelia. Microbiol. Mol. Biol. Rev. 68: 362-372

67. Malejczyk J, Malejczyk M, Kock A, Urbanski A, Majewski S, Hunzelmann N Jablonska S, Orth $G$ and Luger TA (1992) Autocrine growth limitation of human papillomavirus type 16-harboring keratinocytes by constitutively released tumor necrosis factor-alpha. J. Immunol. 149: 2702-2708

68. Delvenne P, al-Saleh W, Gilles C, Thiry A and Boniver J (1995) Inhibition of growth of normal and human papillomavirus-transformed keratinocytes in monolayer and organotypic cultures by interferon-gamma and tumor necrosis factor-alpha. Am. J. Pathol. 146: 589-598

69. Villa LL, Vieira KB, Pei XF and Schlegel R (1992) Differential effect of tumo necrosis factor on proliferation of primary human keratinocytes and cell lines containing human papillomavirus types 16 and 18. Mol. Carcinog. 6: 5-9

70. Basile JR, Zacny V and Munger K (2001) The cytokines tumor necrosis factoralpha (TNF-alpha) and TNF-related apoptosis-inducing ligand differentially modulate proliferation and apoptotic pathways in human keratinocytes expressing the human papillomavirus-16 E7 oncoprotein. J. Biol. Chem. 276: 22522-22528

71. Boccardo E, Noya F, Broker TR, Chow LT and Villa LL (2004) HPV-18 confers resistance to TNF-alpha in organotypic cultures of human keratinocytes. Virology 328: 233-243
72. Thompson DA, Zacny V, Belinsky GS, Classon M, Jones DL, Schlegel R and Munger K (2001) The HPV E7 oncoprotein inhibits tumor necrosis factor alpha-mediated apoptosis in normal human fibroblasts. Oncogene 20: 3629-3640

73. Stoppler H, Stoppler MC, Johnson E, Simbulan-Rosenthal CM, Smulson ME, lyer S, Rosenthal DS and Schlegel R (1998) The E7 protein of human papillomavirus type 16 sensitizes primary human keratinocytes to apoptosis. Oncogene 17: 1207-1214

74. Van Antwerp DJ, Martin SJ, Verma IM and Green DR (1998) Inhibition of TNFinduced apoptosis by NF-kappa B. Trends Cell Biol. 8: 107-111

75. Liston P, Young SS, Mackenzie AE and Korneluk RG (1997) Life and death decisions: the role of the IAPs in modulating programmed cell death. Apoptosis 2: 423-441

76. Bhardwaj A and Aggarwal BB (2003) Receptor-mediated choreography of life and death. J. Clin. Immunol. 23: 317-332

77. Lichtenstein DL, Toth K, Doronin K, Tollefson AE and Wold WS (2004) Functions and mechanisms of action of the adenovirus E3 proteins. Int. Rev. Immunol. 23: 75-111

78. Mahr JA and Gooding LR (1999) Immune evasion by adenoviruses. Immunol. Rev. 168: 121-130

79. McNees AL and Gooding LR (2002) Adenoviral inhibitors of apoptotic cell death. Virus Res. 88: 87-101

80. Duerksen-Hughes PJ, Wold WS and Gooding LR (1989) Adenovirus E1A renders infected cells sensitive to cytolysis by tumor necrosis factor. J. Immunol. 143: 4193-4200

81. Duerksen-Hughes PJ, Hermiston TW, Wold WS and Gooding LR (1991) The amino-terminal portion of $\mathrm{CD} 1$ of the adenovirus E1A proteins is required to induce susceptibility to tumor necrosis factor cytolysis in adenovirus-infected mouse cells. J. Virol. 65: 1236-1244

82. Carrasco RA, Stamm NB and Patel BKR (2003) One-step cellular caspase $3 / 7$ assay. BioTechniques 34: 1064-1067 